\title{
Dendritic Cell-Based Immunotherapy in Multiple Myeloma: Challenges, Opportunities, and Future Directions
}

\author{
Emma Verheye ${ }^{1,2,3}$, Jesús Bravo Melgar ${ }^{2,3}$, Sofie Deschoemaeker ${ }^{2,3} \oplus^{\circ}$, Geert Raes ${ }^{2,3}{ }^{\circ}$, Anke Maes ${ }^{1}$, \\ Elke De Bruyne ${ }^{1}\left(\mathbb{D}\right.$, Eline Menu ${ }^{1}\left(\mathbb{D}\right.$, Karin Vanderkerken ${ }^{1}$, Damya Laoui ${ }^{2,3, *(\mathbb{D})}$ and Kim De Veirman $1, *(\mathbb{C})$ \\ 1 Laboratory of Hematology and Immunology, Myeloma Center Brussels, Vrije Universiteit Brussel, \\ 1090 Brussel, Belgium; emma.mariette.verheye@vub.be (E.V.); anke.maes@vub.be (A.M.); \\ elke.de.bruyne@vub.be (E.D.B.); eline.menu@vub.be (E.M.); karin.vanderkerken@vub.be (K.V.) \\ 2 Laboratory of Myeloid Cell Immunology, VIB Center for Inflammation Research, 1050 Brussels, Belgium; \\ jesus.bravo.melgar@vub.be (J.B.M.); sofie.deschoemaeker@vub.be (S.D.); geert.raes@vub.be (G.R.) \\ 3 Laboratory of Cellular and Molecular Immunology, Vrije Universiteit Brussel, 1050 Brussels, Belgium \\ * Correspondence: dlaoui@vub.be (D.L.); kim.de.veirman@vub.be (K.D.V.); Tel.: +32-2-629-1978 (D.L.); \\ $+32-2-477-4535$ (K.D.V.)
}

\section{check for}

updates

Citation: Verheye, E.; Bravo Melgar,

J.; Deschoemaeker, S.; Raes, G.; Maes,

A.; De Bruyne, E.; Menu, E.;

Vanderkerken, K.; Laoui, D.; De

Veirman, K. Dendritic Cell-Based Immunotherapy in Multiple

Myeloma: Challenges, Opportunities, and Future Directions. Int. J. Mol. Sci. 2022, 23, 904. https://doi.org/ 10.3390/ijms23020904

Academic Editor: Domenico Galati

Received: 23 December 2021

Accepted: 11 January 2022

Published: 14 January 2022

Publisher's Note: MDPI stays neutral with regard to jurisdictional claims in published maps and institutional affiliations.

Copyright: (C) 2022 by the authors. Licensee MDPI, Basel, Switzerland. This article is an open access article distributed under the terms and conditions of the Creative Commons Attribution (CC BY) license (https:// creativecommons.org/licenses/by/ $4.0 /)$.

\begin{abstract}
Immunotherapeutic approaches, including adoptive cell therapy, revolutionized treatment in multiple myeloma (MM). As dendritic cells (DCs) are professional antigen-presenting cells and key initiators of tumor-specific immune responses, DC-based immunotherapy represents an attractive therapeutic approach in cancer. The past years, various DC-based approaches, using particularly ex-vivo-generated monocyte-derived DCs, have been tested in preclinical and clinical MM studies. However, long-term and durable responses in MM patients were limited, potentially attributed to the source of monocyte-derived DCs and the immunosuppressive bone marrow microenvironment. In this review, we briefly summarize the DC development in the bone marrow niche and the phenotypical and functional characteristics of the major DC subsets. We address the known DC deficiencies in MM and give an overview of the DC-based vaccination protocols that were tested in MM patients. Lastly, we also provide strategies to improve the efficacy of DC vaccines using new, improved DC-based approaches and combination therapies for MM patients.
\end{abstract}

Keywords: multiple myeloma; dendritic cells; immunotherapy; vaccination

\section{Introduction}

Multiple myeloma (MM) is the second most common hematological malignancy. Due to the uncontrolled proliferation and subsequent accumulation of a single clone of terminally differentiated B cells in the bone marrow (BM) niche, advanced stages of MM are accompanied by clinical features, such as anemia, renal failure, and hypercalcemia in conjunction with osteolytic bone lesions [1]. MM cells secrete a monoclonal immunoglobulin (M-protein) with specific antigenic determinants, the idiotype (Id), which can be considered as a tumor-associated antigen [2]. MM evolves from an asymptomatic premalignant stage termed monoclonal gammopathy of undetermined significance (MGUS) that can progress into smoldering MM (SMM) and, lastly, into active/symptomatic MM [3]. Patients are primarily diagnosed at the age of 65-70 years; however, 37\% are younger than 65 years, and the majority of patients eventually succumb to progressive disease (PD) with a median life expectancy of 5-7 years [4,5].

High-dose chemotherapy followed by autologous hematopoietic stem-cell transplantation (auto-HSCT) is considered the standard of care for the younger, more fit MM patients (less than 70 years of age). For transplant-ineligible MM patients, the treatment has evolved significantly over the last decades from alkylating agents and steroids to triple and quadruple combinations including proteasome inhibitors (e.g., bortezomib, carfilzomib) and immunomodulatory drugs (e.g., lenalidomide) [6,7]. The past years, immunotherapy has 
opened a new era in the treatment of MM [8]. Monoclonal antibodies, bispecific antibodies, immune checkpoint inhibitors, vaccines, and adoptive $\mathrm{T}$ cell therapies have been actively investigated, and some of them achieved remarkable clinical successes in MM patients [8]. The monoclonal CD38-targeting antibodies daratumumab or isatuximab, CS1-targeting elotuzumab, and the B-cell maturation antigen (BCMA)-targeting antibody drug conjugate belantamab mafodotin are approved drugs for the treatment of MM [8-10]. In 2021, the Food and Drug Administration (FDA) approved abecma (idecabtagene vicleucel), the first chimeric antigen receptor (CAR) T cell therapy for MM patients [11,12]. Despite the advances in cancer immunotherapy, the majority of patients still relapse, and responses are hampered by immune escape mechanisms and the presence of an immunosuppressive BM microenvironment.

Immune dysfunction and immunosuppression are both hallmarks of MM disease [13-15]. Common immunodeficiencies include (a) dysfunctional CD8 ${ }^{+} \mathrm{T}$ cells and natural killer (NK) cells [16], (b) the imbalanced production of immunogenic and tolerogenic cytokines [17,18], (c) upregulated inhibitory immune checkpoints [19], (d) impaired antigen presentation capacity $[20,21]$, and (e) infiltration of immunosuppressive cells in the BM niche. Myeloidderived suppressor cells (MDSCs), tumor-associated macrophages (TAMs), regulatory $\mathrm{T}$ cells (Tregs), $\mathrm{T}$ helper (Th) 17 cells, and mesenchymal stromal cells are major cellular components of this suppressive microenvironment [14,22-24] and contribute to MM cell survival and drug resistance.

The use of dendritic cells (DCs) as a platform for cancer vaccine development is another safe and promising strategy to enhance tumor-specific host immune responses $[25,26]$. DCs are indispensable for an adequate immune response, as they bridge the innate and the adaptive immune system in response to different pathogens, viruses, bacteria, and even tumor cells. As master antigen-presenting cells (APCs) present in all tissues, DCs capture, process, and present tumor-(neo)antigens to naïve $\mathrm{T}$ cells via major histocompatibility complex (MHC) molecules. Depending on the antigen (Ag) nature, with MHC-I presenting endogenous Ags and MHC-II presenting exogenous Ags, DCs elicit adaptive CD8 ${ }^{+}$or $\mathrm{CD}^{+}$ $\mathrm{T}$ cell immune responses, respectively [27]. Due to their capacity for cross-presenting Ags and inducing specific cellular (T cells) and humoral (B cells) immune responses, DCs are a promising tool for immunotherapy in MM. However, in the context of cancer, it is important to note that DCs can also exert immunosuppressive and pro-tumoral effects either by an increased expression of immune checkpoints or by the elaboration of tolerogenic signals. On the other hand, DCs can also themselves be suppressed, for instance, by tumor-derived cytokines and immunosuppressive cells, such as Tregs [28-30].

Over the past decades, many DC-based therapies have been clinically tested in MM; however, long-term clinical responses were rather inconsistent [31,32]. In this review, we briefly discuss the development as well as the phenotypical and functional characteristics of the major DC subsets in the BM. Further details concerning the challenges, the opportunities, and the future directions of DC-based immunotherapy in MM are addressed focusing on the DC deficiencies in the BM niche, the currently used DC-based vaccination strategies in clinical trials, and the therapeutic potential of new, improved DC-based approaches, and combination therapies for MM patients.

\section{Dendritic cell (DC) origin and Function in Healthy Tissue}

\subsection{Development of DCs in the BM Niche}

DCs, named after the Greek word "dendron" because of their tree-like morphology, were first documented by Steinman and Cohn in 1973. Of note, this discovery was awarded the 2011 Nobel Prize in Physiology or Medicine [33].

Over the last few decades, great attention has been given to DC biology in healthy and malignant tissue. DC characterization reveals a heterogeneous cell population, with each subset having its specific lineage, markers, location, migratory, and functional capacity. An ongoing debate concerns the DC classification system and nomenclature, as it is a difficult and controversial subject. Guilliams et al. proposed a nomenclature for 
mononuclear phagocytes by classifying cells primarily according to the ontogeny and secondary by the location, function, and phenotype [34]. Currently, two ontogenically distinct DC subsets are described: classical/conventional DCs (cDCs) and plasmacytoid DCs (pDCs). Furthermore, an additional subset including monocyte-derived cells also referred to as monocyte-derived DCs (moDCs) is worth mentioning. However, there is some disagreement among researchers as to whether to classify these cells as macrophages or as DCs [34-36].

Even though the DC subsets differ in several aspects, they all arise from a multipotent hematopoietic stem cell (HSC; CD34+) located in the BM in a stepwise differentiation process called "hematopoiesis". Due to lineage-specific nuclear transcription regulatory factors, these HSC differentiate into the desired cell type and the specific subtypes. First, the HSCs develop into two different cell lineages: common lymphoid progenitor (CLP) and common myeloid progenitor (CMP) cells [37]. It is the latter that has generally been acknowledged to give rise to the different DCs subsets since the CMP cells differentiate into granulocyte macrophage DC precursors (GMDP), with the prospect to develop granulocyte, macrophage and DC populations. Subsequently, GMDPs differentiate into macrophage DC progenitors (MDP) and common DC progenitors (CDPs) with the capacity to give rise to pre-cDCs and pre-pDCs. While pre-pDCs produce $\mathrm{pDC}$ in the BM, pre-cDCs are already committed to the $\mathrm{CDC} 1$ and $\mathrm{CDC} 2$ lineage in the $\mathrm{BM}$ niche (termed pre-cDC1 and pre-cDC2) [38-40]. Following this differentiation process, pre-cDCs and pDCs leave the $\mathrm{BM}$ and enter the circulation where the pre-cDCs differentiate into fully functioning $\mathrm{CDC} 1$ and $\mathrm{cDC} 2$ [41-43]. Although this suggests that $\mathrm{CDCs}$ and pDCs derive from CMPs, other studies suggest that pDCs arise from other precursors, namely CLPs [39,44-46]. In addition, moDCs differentiate from blood circulating monocytes in inflammatory conditions.

DC development is strongly cytokine dependent. An important cytokine for DC development is the FMS-like tyrosine kinase 3 ligand (FLT3L) [47]. Pulendran et al. found that humans injected with FLT3L showed increased numbers of pDCs, cDC1s, and cDC2s [48]. However, the differentiation into a specific subtype required specific transcription factors, particularly IRF8 and IRF4 [49]. The distinct DC subsets are described below in more detail and summarized in Figure 1.

\begin{tabular}{|c|c|c|c|c|}
\hline DC subsets & CDC1 & $\mathrm{cDC2}$ & $\mathrm{pDC}$ & MoDC \\
\hline $\begin{array}{l}\text { Human } \\
\text { surface } \\
\text { markers }\end{array}$ & $\begin{array}{c}\text { BTLA (CD272) } \\
\text { CADM1 (NECL2) } \\
\text { CLEC9A (DNGR-1) } \\
\text { BDCA3 (CD141) } \\
\text { XCR1 }\end{array}$ & $\begin{array}{c}\text { CD11b } \\
\text { SRRPa (CD172a) } \\
\text { BDCA1 (CD1c) }\end{array}$ & $\begin{array}{c}\mathrm{CD} 123(\mathrm{IL} 3 \mathrm{Ra}) \\
\text { BDCA2 (CD303, CLEC4C) } \\
\text { BDCA4 (CD304) } \\
\text { CD45RA (B220) }\end{array}$ & $\begin{array}{c}\text { CCR2 } \\
\text { CD14 } \\
\text { CD64 (FcyR1) } \\
\text { CD16 (FcyR3) }\end{array}$ \\
\hline $\begin{array}{l}\text { Mouse } \\
\text { surface } \\
\text { markers }\end{array}$ & $\begin{array}{c}\text { CD8a (Lymphoid) } \\
\text { CD103a (Non-lymphoid) } \\
\text { CD24 } \\
\text { Clec9A } \\
\text { XCR1 }\end{array}$ & $\begin{array}{c}\text { CD11b } \\
\text { SIRPa (CD172a) }\end{array}$ & $\begin{array}{c}\text { CD317 } \\
\text { Siglec-H } \\
\text { CD45RA (B220) }\end{array}$ & $\begin{array}{c}\text { CCR2 } \\
\text { CD14 } \\
\text { CD64 (FcyR1) } \\
\text { CD16 (FcyR3) }\end{array}$ \\
\hline $\begin{array}{l}\text { Primary } \\
\text { functions }\end{array}$ & $\begin{array}{l}\text { Cross-presentation } \\
\text { Cellular immune response }\end{array}$ & $\begin{array}{l}\text { Humoral immune } \\
\text { response }\end{array}$ & $\begin{array}{l}\text { IFN- } \alpha / \beta \text { production } \\
\text { Antiviral immune } \\
\text { response }\end{array}$ & Inflammatory control \\
\hline
\end{tabular}

Figure 1. The distinct DC subsets with their respective surface markers (human and mouse) and primary functions. Markers can vary across tissues and depend on the physiological setting. CDC1, type 1 classical/conventional dendritic cell; cDC2, type 2 classical/conventional dendritic cell; pDC, plasmacytoid dendritic cell; moDC, monocyte-derived dendritic cell; BTLA, B and T cell lymphocyte attenuator; CADM1, cell adhesion molecule 1; CLEC9A, C-type-lectin 9A; BDCA3, blood dendritic cell antigen 3; XCR1, XC chemokine receptor 1; CLEC10A, C-type-lectin 10A; BDCA1, blood dendritic cell antigen 1; IL3R $\alpha$, interleukin 3R $\alpha$; BDCA2, blood dendritic cell antigen 2; CLEC4C, C-type-lectin C4; BDCA4, blood dendritic cell antigen 4; Siglec-H, sialic acid-binding immunoglobulin-like lectin- $\mathrm{H}$; CCR2, C-C motif chemokine receptor 2; Fc $\gamma$ R1, Fc-gamma receptor 1; Fc $\gamma$ R3, Fc-gamma receptor 3. 


\subsection{Subsets}

\subsubsection{Classical or Conventional DCs (cDCs)}

cDCs, sometimes referred to as myeloid DCs, can be further subdivided into two main subpopulations termed $\mathrm{CDC} 1$ and $\mathrm{CDC} 2$. Both subsets are present in lymphoid (e.g., spleen, lymph nodes, and $\mathrm{BM}$ ) and non-lymphoid tissues (e.g., lung and skin). In humans, the $\mathrm{CDC} 1 \mathrm{~s}$ are characterized by the low expression of $\mathrm{CD} 11 \mathrm{~b}$ and the high expression of $\mathrm{B}$ and T cell lymphocyte attenuator (BTLA; CD272), cell adhesion molecule 1 (CADM1; also known as NECL2), C-type-lectin CLEC9A (also known as DNGR-1), and blood dendritic cell antigen 3 (BDCA3; also known as CD141) [50-52]. Comparative studies revealed a corresponding $\mathrm{cDC} 1$ subpopulation in mice. Murine $\mathrm{cDC} 1 \mathrm{~s}$, found in lymphoid tissues, are characterized by $\mathrm{CD} 8 \alpha^{+}$expression, whereas their counterpart in non-lymphoid organs features $\mathrm{CD}_{103}{ }^{+}$expression $[50,53]$. In addition, mouse $\mathrm{CDC} 1 \mathrm{~s}$ can be distinguished from other DC subtypes due to high levels of Clec9A [54]. Since the $\mathrm{CDC1}$ subpopulation is identified across species (mice and humans), a unifying marker, the XC chemokine receptor 1 (XCR1), has been reported [50,54]. On the other hand, cDC2s in humans are identified by the markers CD11b, SIRP $\alpha$ (CD172a), and BDCA1 (also known as CD1c), while the murine equivalent is generally characterized by the markers CD11b and SIRP $\alpha$ (CD172a) [53]. In addition to $\mathrm{CDC} 1$ and $\mathrm{CDC} 2$, migratory DCs (mig-DCs, also termed mregDC, $\mathrm{LAMP3}^{+} \mathrm{DC}$, or DC3) were recently identified as a distinct DC cluster that is present in various tumor models. These cells are mature DCs enriched in immunoregulatory molecules, and it has been suggested that both $\mathrm{CDC} 1$ and $\mathrm{CDC} 2$ can differentiate into mig-DCs [55-58].

The differentiation into specific $\mathrm{CDC}$ subsets is coordinated by specific transcription factors. Inhibitor of DNA binding 2 (ID2) [59], basic leucine zipper ATF-like 3 transcription factor (BATF3) [60], nuclear factor interleukin 3 regulated (NFIL3) [61], and the interferon regulatory factor 8 (IRF8) [62] are required for $\mathrm{CDC} 1$ specific differentiation. Upon deletion of either of these genes, the development of $\mathrm{CD} 8 \alpha^{+}$and $\mathrm{CD} 103^{+} \mathrm{CDC} 1 \mathrm{~s}$ was found to be defective, while $\mathrm{CD} 11 \mathrm{~b}^{+} \mathrm{cDC} 2$ development remained unaffected. These findings suggest that the development of both the CD8 $\alpha^{+} \mathrm{cDC} 1 \mathrm{~s}$ in lymphoid tissue and the $\mathrm{CD} 103^{+} \mathrm{cDC} 1 \mathrm{~s}$ in non-lymphoid tissue depends on the same transcription factors [60]. By contrast, Seillet et al. found that these four transcription factors (ID2, IRF8, BATF3, and NFIL3) are necessary for $\mathrm{CD}_{103^{+}} \mathrm{CDC} 1$ development, while only IRF8 seems to be important for CD8 $\alpha^{+} \mathrm{CDC} 1 \mathrm{~s}$ development [63]. Furthermore, cDC2 specific differentiation depends on the transcription factors zinc finger E box-binding homeobox 2 (ZEB2) [64], reticuloendotheliosis viral oncogene homolog B (RelB) [65], PU.1 [66], recombining binding protein suppressor of hairless (RBP-J) [67], neurogenic locus notch homolog protein 2 (NOTCH2) [68], IRF2 [69], and IRF4 [62]. Further characterization of the murine $\mathrm{CDC} 2$ subsets by Brown et al. revealed two novel $\mathrm{CDC} 2$ subsets, termed $\mathrm{CDC} 2 \mathrm{~A}$ and $\mathrm{CDC} 2 \mathrm{~B}$, which are defined by the transcription factors T-bet and $R O R \gamma t$, respectively [70]. Villani et al. described the analogy of the murine $\mathrm{CDC} 2 \mathrm{~A}$ and $\mathrm{CDC} 2 \mathrm{~B}$ subtypes with novel human blood $\mathrm{CDC} 2\left(\mathrm{CD} 1 \mathrm{c}^{+}\right)$subsets, termed $\mathrm{DC} 2$ and DC3. These human $\mathrm{CDC} 2$ subsets have been described as $\mathrm{CD} 32 \mathrm{~B}^{+} \mathrm{CD} 1 \mathrm{c}^{+} \mathrm{cDC} 2$ and $\mathrm{CD} 163^{+} \mathrm{CD} 1 \mathrm{c}^{+} \mathrm{CDC} 2$, respectively $[70,71]$. Based on the subsequent inflammatory potential and maturation state of the human $\mathrm{CDC} 2$ subsets, Dutertre et al. further described three different subpopulations within the DC3 subset as follows: $\mathrm{CD}^{-} \mathrm{CD} 163^{-} \mathrm{cDC} 2 \mathrm{~s}$, $\mathrm{CD}^{-}{ }^{-\mathrm{CD} 163^{+}}{ }^{\mathrm{cDC} 2 \mathrm{~s} \text {, and } \mathrm{CD} 5}{ }^{-} \mathrm{CD} 163^{+} \mathrm{CD} 14^{+} \mathrm{cDC} 2 \mathrm{~s}$ [72].

\subsubsection{Plasmacytoid DCs (pDCs)}

pDCs share several characteristics with cDCs, as they are both strongly FLT3L-dependent during development $[47,73]$. In addition, $\mathrm{pDC}$ development depends on specific transcriptional regulators, including E2-2, Spi-B, IRF8, and ID2 in humans and mice $[62,64,74,75]$. pDCs are $\mathrm{CD} 11 \mathrm{c}^{\text {low }}, \mathrm{MHC}^{-\mathrm{II}^{+}}, \mathrm{CD} 317^{+}$, and sialic acid-binding immunoglobulin-like lectin$\mathrm{H}\left(\right.$ Siglec- $\left.\mathrm{H}^{+}\right)$in mice. In human, $\mathrm{pDC}$ are characterized by CD123 (IL3R $\left.\alpha\right)$, BDCA2 (CD303, CLEC4C), and BDCA4 (CD304) expression [40,52,76]. The unifying marker CD45RA (B220) identifies both mouse and human pDCs $[46,76]$. 


\subsubsection{Monocyte-Derived DCs (moDCs)}

Inflammatory DCs are DCs originating from circulating blood monocytes upon inflammatory conditions that include phenotypes previously described as monocyte-derived cells, TNF $\alpha$ /iNOS-producing DCs (Tip-DCs), or moDCs [77]. Upon injury, CCR2 controls the exit of monocytes $\left(\mathrm{Ly}_{6} \mathrm{C}^{+}\right)$out of the BM and the consequent invasion into the inflammatory tissue. Subsequently, these infiltrated monocytes fully differentiate into moDCs in response to growth factors, such as granulocyte-macrophage colony-stimulating factor (GM-CSF) or Toll-like receptor 4 (TLR4) ligands. Similar to cDC2s, moDCs depend on the transcription factor IRF4 for differentiation $[77,78]$. Furthermore, the phenotypic profile of moDCs is highly similar to that of the CDCs since both subtypes are expressing CD11c, MHC-II, and CD11b molecules on their surface. The markers $\mathrm{C}-\mathrm{C}$ motif chemokine receptor 2 (CCR2) and Fc-gamma receptor 1 (Fc $\gamma$ R1; CD64) distinguish moDCs from cDCs, as they are remnants from their monocytic past [79]. In summary, human and murine moDCs are $\mathrm{CD}_{11}{ }^{+}, \mathrm{MHC}-\mathrm{II}^{+}, \mathrm{F} 4 / 80^{-}, \mathrm{CCR} 2^{+}, \mathrm{CD}^{+} 4^{+}, \mathrm{CD}^{+} 4^{+}\left(\mathrm{Fc} \gamma \mathrm{R} 1^{+}\right)$, and CD16 ${ }^{+}\left(\mathrm{Fc} \gamma \mathrm{R} 3^{+}\right)[40,80]$.

\subsection{Biology in Healthy Tissue}

DCs are master APCs that bridge the innate and the adaptive immune system and are therefore indispensable for an adequate immune response [27]. DCs arise in the BM niche in an immature state, after which they distribute in lymphoid and non-lymphoid tissues. In peripheral tissue, immature DCs (imDCs) are capable of recognizing and capturing Ags as well as tumor-(neo)antigens. As sentinel cells of the innate immune system, DCs are able to recognize endogenous danger molecules, called damage-associated molecular pattern molecules (DAMPs) that are released by damaged or dying cells, via pattern recognition receptors (PRRs) on the cell surface. Subsequently, DCs secrete the necessary cytokines allowing the activation of innate immune cells [81]. Simultaneously, DCs process and present these Ags on the cell surface, allowing imDCs to switch into mature DCs (mDCs). While imDCs are characterized by low levels of co-stimulatory molecules (CD80, CD86, and CD83) and the low secretion level of immunostimulatory cytokines (interleukin-12 (IL-12), IL-10, and tumor necrosis factor (TNF)), mDCs express high levels of co-stimulatory molecules and immunostimulatory cytokines [82]. In addition, imDCs conserve the MHC-II molecules in the late-endosomal and lysosomal compartments, whereas in mDCs, they are located on the cell surface [83]. Upon Ag presentation via MHC molecules, mDCs migrate to draining lymph nodes in a chemokine-dependent manner [84]. CCR7 and its cognate ligands, the C-C motif ligand (CCL)-19 and CCL-21, allow homing of DCs through the lymphatic vessels to the T lymphocyte-enriched zone in the secondary lymphoid organs [84-86]. In the draining lymph nodes, $\mathrm{mDC}$ trigger naïve $\mathrm{T}$ cells to differentiate into diverse effector T cells, including Th1 cells, Th2 cells, Th17 cells, T follicular helper (TFH) cells, Tregs, and CD8 ${ }^{+}$cytotoxic T lymphocytes (CTLs), resulting in specific T cell responses [87,88]. Depending on the Ag nature, with MHC-I presenting endogenous Ags and MHC-II presenting exogenous Ags, DCs elicit adaptive CD8 ${ }^{+}$or $\mathrm{CD} 4^{+} \mathrm{T}$ cell immune responses, respectively. However, an interesting process called "cross-presentation" allows the presentation of exogenous Ags on MHC-I molecules instead of on MHC-II molecules, resulting in $\mathrm{CD}^{+} \mathrm{CTL}$ activation [89].

In more detail, each DC subset contributes differently to the immune response. For instance, $\mathrm{CDC} 1 \mathrm{~s}$ excel in cross-presenting exogenous Ags via MHC-I to CD8 ${ }^{+} \mathrm{CTL}$ and secrete IL-12, thereby promoting Th1 responses [49,90]. In addition, cDC1s are experts in activating NK cells and NKT cells. Both functional properties make them superior for inducing an effective anti-tumor immune response. By contrast, cDC2s are excellent activators of, preferably, $\mathrm{CD} 4^{+} \mathrm{T}$ cells (to a lesser extend $\mathrm{CD} 8^{+} \mathrm{T}$ cells), allowing the induction of Th1, Th2, and Th17 via MHC-II molecules [91]. As a result, cDCs are crucial for activating and maintaining a specific immune response, with $\mathrm{CDC} 1$ mainly initiating a cellular immune response and $\mathrm{cDC} 2$ a humoral immune response. Furthermore, functional experiments showed that the recently described $\mathrm{CDC} 2$ subpopulations exert distinct immune responses. The $\mathrm{CDC} 2 \mathrm{~A}$ subpopulation is involved in anti-inflammatory control, whereas the $\mathrm{CDC} 2 \mathrm{~B}$ 
subpopulation is found to produce TNF $\alpha$ and IL-6 [70]. Recently, some cDC2 subsets were also shown to cross-present $\mathrm{Ag}$ to $\mathrm{CD}^{+} \mathrm{T}$ cells $[92,93]$ or further activate existing $\mathrm{CD}^{+} \mathrm{T}$ cells [94]. The human blood DC2 and DC3 subsets are shown to be potent stimulators of naïve $\mathrm{T}$ cell proliferation [71]. In addition, $\mathrm{pDC}$ are essential for regulating an antiviral innate immune response, as their activated state is capable of secreting large amounts of interferon- $\alpha / \beta$ (IFN- $\alpha / \beta)$ upon TLR7/9 stimulation [95]; however, overproduction of IFN$\alpha / \beta$ is associated with autoimmune disorders. Furthermore, in several cancers, pDCs are correlated with a poor prognosis, as they promote immunosuppression by the expansion and activation of Tregs [96]. In contrast to cDCs, pDCs are limited in their ability to activate naïve $\mathrm{CD}^{+}$and $\mathrm{CD}^{+} \mathrm{T}$ cells [97]. Finally, moDCs, differentiated from monocytes that were recruited to the site of injury, play a major role in inflammatory control. MoDCs have been widely tested in several clinical settings and are found to be prominent in Ag uptake and processing; however, their Ag presentation capacity, migration potential to the lymph node, and the secretion capacity of crucial cytokines (e.g., IL12p70) is less efficient [98-100].

Importantly, due to the capacity of DCs for Ag (cross-)presentation and the induction of specific cellular ( $\mathrm{T}$ cells) and humoral (B cells) immune responses, DCs are a promising tool for immunotherapy. However, in literature, it has been described that DCs collected from MM patients feature defective immunological properties, supporting MM pathogenesis $[20,21,101]$.

\section{DC Deficiencies in Multiple Myeloma (MM)}

DC deficiencies in MM are summarized in Figure 2 and are known to play an important role in MM pathophysiology, as they lack their proper immunological capacity, resulting in drug resistance and the subsequent failure of current immunotherapeutic approaches. Despite numerous studies on DC deficiencies in MM, the presence and function of the different DC subsets, particularly the cDC subsets, remains to be elucidated. Several researchers investigated the number, phenotypic profile, and functional status of DCs during MM disease progression. The number of circulating DCs in healthy individuals includes $0.1-2.0 \%$ of the mononuclear cells [102,103]. However, a significant difference between MM patients and healthy individuals has been observed, with approximately a $50 \%$ reduction in myeloid DCs $\left(\mathrm{BDCA}^{+}\right)$and $\mathrm{pDCs}\left(\mathrm{BDCA}^{+}\right)$in the peripheral blood (PB) of MM patients $[20,21,101]$. This reduction in PBDCs is independent of the patient's disease stage (stage I vs. stage III MM) [20]. Regarding the BM DC number, Leone et al. found that during disease progression from MGUS to active/symptomatic MM, the myeloid DCs $\left(C D 11 c^{+}\right)$and pDCs $\left(C D 11 c^{-} \mathrm{CD}^{2} 3^{+}\right)$accumulate in the BM niche [104]. Moreover, this accumulation is accompanied by an increased tumor burden, as they exert immunosuppressive and tumor-promoting properties [104,105].

Besides the changes in DC numbers, significant alterations of the phenotypic profile of DCs have been observed in MM patients. CCR5, CCR7, and DEC-205 expression was down-regulated on myeloid DCs $\left(B D C A-1^{+}\right)$and pDCs $\left(B D C A-2^{+}\right)$in PB from MM patients when compared to those derived from healthy controls [21]. Immature DCs migrate to the site of inflammation under the guidance of CCR5, while migration of mature DCs to the secondary lymph nodes is controlled by CCR7 [21]. Consequently, reduced expression of CCR5 and CCR7 molecules in MM DCs is associated with disturbed DC migration, whereas reduced expression of DEC-205 decreases Ag uptake. In addition, the significantly lower expression of HLA-DR molecules and co-stimulatory molecules, such as CD80/86 and CD40, may indicate that PBDCs (myeloid DCs (BDCA- $1^{+}$or CD11c ${ }^{+} \mathrm{CD}_{3} 3^{+}$) and pDCs $\left(\mathrm{BDCA}-2^{+}\right.$or $\left.\mathrm{CD} 123^{+}\right)$) in $\mathrm{MM}$ patients are in an immature state and as a consequence possess impaired Ag presentation capacities [20,21]. As a result, T cell proliferation and activation are insufficient, lacking a proper immune response. 


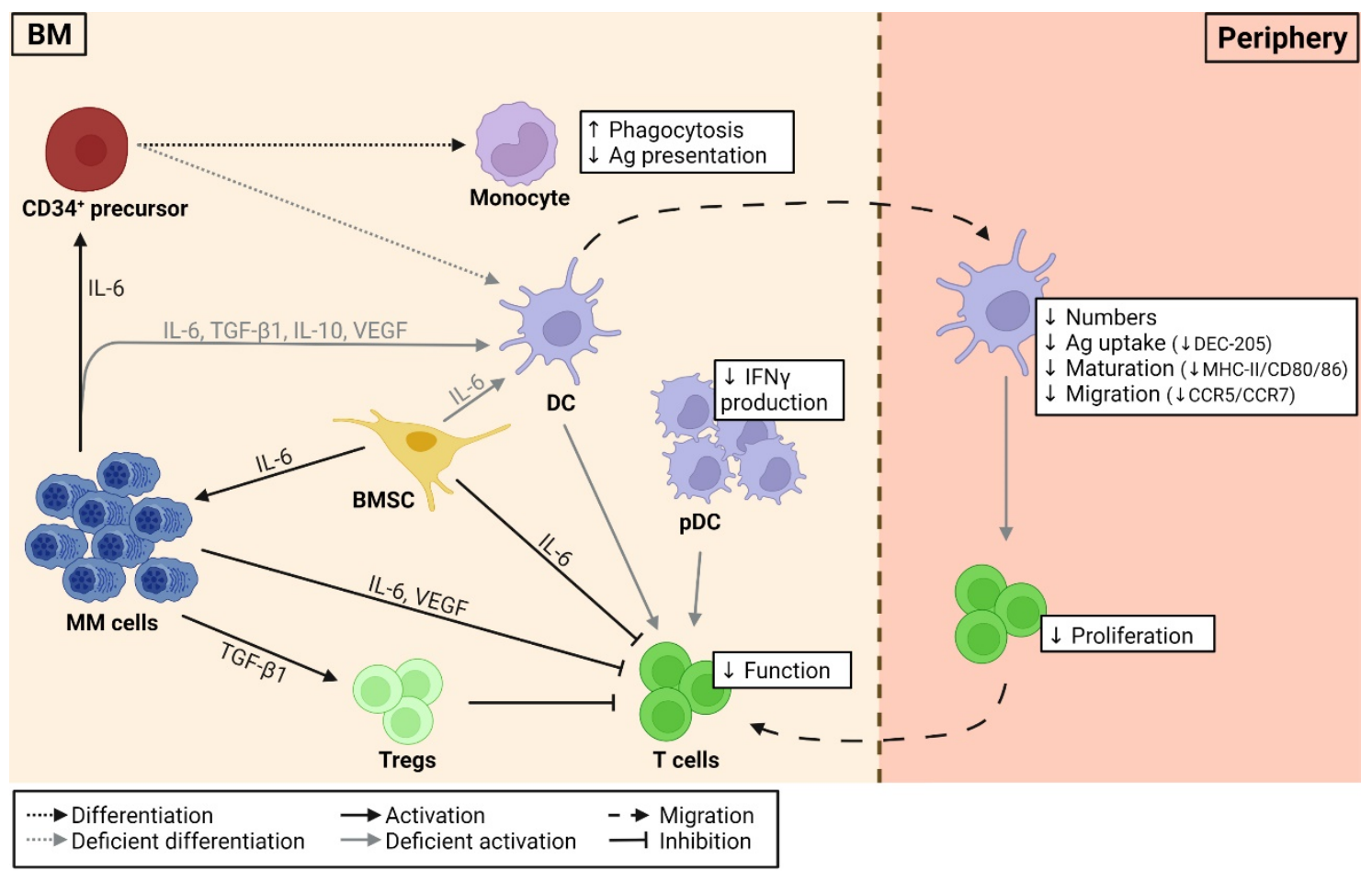

Figure 2. Schematic overview of the factors engaged in DC deficiencies in MM. DC differentiation, maturation, and activation are hampered by tumor microenvironmental factors. Tumor-derived cytokines, such as IL-6, promote $\mathrm{CD} 34^{+}$precursor cell differentiation into monocytic cells instead of DC progenitors, whereas TGF- $\beta 1$, VEGF, and IL-6/-10 are found to be responsible for impaired DC maturation (decreased MHC-II/CD40/CD80/86) and function (decreased CCR5/CCR7/DEC205). Impaired DCs lack efficient $T$ cell activation. Tumor-derived factors, such as IL-6 and VEGF, can directly inhibit $\mathrm{T}$ cell function, whereas TGF- $\beta 1$ favors the differentiation and expansion of Tregs, which on their terms suppress T cell function. pDCs, found in MM patients, show defective interferon (IFN) $\gamma$ production and accumulate in the BM niche, exerting immunosuppressive and tumor-promoting properties. The tumor microenvironment promotes MM cells survival through, for instance, the secretion of IL-6 by BMSCs. DC, dendritic cell; MM, multiple myeloma; BM, bone marrow; Ag, antigen; BMSCs, BM stromal cells; pDC, plasmacytoid DCs; Tregs, regulatory T cells; IL-6, interleukin 6; TGF- $\beta 1$, transforming growth factor- $\beta 1$; VEGF, vascular endothelial growth factor.

Phenotypic alterations and functional deficiencies, which include impaired DC differentiation, maturation, and activation, are influenced by immunological inhibitory cytokines present in the tumor microenvironment (Figure 2). The most commonly involved cytokines are transforming growth factor- $\beta 1$ (TGF- $\beta 1$ ), vascular endothelial growth factor (VEGF), IL-6, and IL-10. These factors can induce hyperactivation of the STAT3 and extracellular signal-regulated kinase (ERK) pathways, which may be taken accountable for defective DC differentiation [106,107]. TGF- $\beta 1$ and IL-10 are both secreted by MM cells and are thought to be responsible for deficient CD80/86 upregulation during DC maturation [20,108]. Blocking these molecules with, for instance, anti-TGF- $\beta 1$ or anti-IL-10 antibodies, or by administering IL-12 and IFN- $\gamma$, neutralizes the inhibition in CD80/86 upregulation [109]. In addition, the excessive production of TGF- $\beta 1$ by MM cells suppressed allogeneic T cell responses and favored the differentiation and expansion of Tregs, resulting in tumorassociated immune tolerance [110]. Besides the fact that tumor-derived VEGF is engaged in the impaired DC function due to inhibitory effects on DC maturation and differentiation, it is also responsible for T cell exhaustion [111,112]. Previous research also confirmed the importance of the adhesion of MM cells to BM stromal cells (BMSCs). BMSCs secrete IL-6 in an NF- $\kappa B$-dependent manner, supporting MM cell growth and survival. IL-6, which can also be secreted by MM cells, affects $\mathrm{CD}^{+} \mathrm{T}$ cell differentiation, as it inhibits Th1 polariza- 
tion and promotes Th2 differentiation. Furthermore, IL-6 promotes CD $34^{+}$precursor cell differentiation into monocytic cells instead of DC progenitors through the upregulation of CD14 and downregulation of CD1a, HLA-DR, CD40, and CD80 [20]. As a result, these monocytic cells feature adequate phagocytosis but inadequate Ag presentation. Brimnes et al. were the first to report that $\mathrm{PDCs}\left(\mathrm{BDCA}-2^{+}\right)$, present in MM patients, show defective IFN- $\gamma$ production, which is indispensable for regulating a proper antiviral innate immune response [21]. Wang et al. confirmed the inhibitory effect of tumor-derived IL-6, IL-10, and TGF- $\beta 1$ on DC maturation and function using the 5TGM1 model. This maturation block resulted in a weakened expression of $\mathrm{MHC}$ molecules and co-stimulatory factors on the DC surface and an insufficient capacity of DCs to prime allogeneic T cell responses [113].

In conclusion, $\mathrm{MM}$ cells are considered intelligent evaders of immunosurveillance through their ability to disturb B cell immunity, promote Treg expansion, and suppress CTL activity but, most importantly, because of their negative impact on DC differentiation, maturation, and functions [114].

\section{Current DC-Based Immunotherapies in MM}

DC-based strategies aiming to elicit effective anti-MM immune responses have evolved tremendously over the past few decades. Initial trials made use of the naked idiotypic (Id) protein to immunize MM patients. However, additional attempts using Id-proteins conjugated with immunogenic carriers, such as keyhole limpet hemocyanin (KLH) or GM-CSF, resulted in unsatisfactory immune responses $[2,115,116]$. APCs are, because of their functional properties, suitable natural adjuvants and thus considered a promising tool for cancer immunotherapy, including vaccination therapies. Dabaghao et al. demonstrated that DCs rather than monocytes are the most potent APCs to elicit an efficient primary Idspecific immune response due to their capacity to present (tumor-) Ags via MHC molecules in the context of the necessary co-stimulatory signals [117].

Thus far, several attempts of DC-based strategies in MM have been conducted in a clinical setting. Accordingly, several DC-based vaccination "generations" have emerged over time, evolving from "first-generation" to "second-generation" and the rising "nextgeneration" DC vaccines. Central to the first and second generations are the use of exvivo-generated moDCs. Different protocols for generating a sufficient number of moDCs from human monocytes have been reviewed elsewhere [118]. In summary, adherent peripheral blood mononuclear cells (PBMC; CD14 ${ }^{+}$monocytes), collected through leukapheresis, were cultured in the presence of differentiation cocktails (e.g., GM-CSF, IL-4), resulting in immature moDCs (considered first-generation DC vaccines), and subsequently, maturation cocktails (TNF- $\alpha$, IL-13, stem cell factor (SCF), TGF- $\beta 1$, FLT3L, or CD40 ligand (CD40L)) were used to obtain mature moDCs (considered second generation) [119]. MoDCs were either loaded with Id-proteins [120-133], pulsed with myeloma-associated antigen mRNA (such as MAGE3, BCMA, and Survivin) [134], or fused with whole tumor MM cells [135-137]. In Table 1 and Table 2, we give an overview of the DC-based strategies that were performed in clinical trials for MM patients.

\subsection{The Idiotypic (Id) Protein as MM-Specific Tumor-associated antigen (TAA) for DC-Based Immunotherapy}

Initial clinical trials of DC-based therapies used the Id-protein as MM-specific tumorassociated antigen (TAA) in order to elicit specific immune responses in advanced-stage MM patients [120,121,126,128,131]. For instance, Wen and colleagues were the first to report DC-based immunotherapy in a 43-year-old MM patient. Prior to DC vaccination, the patient's serum Id level was $31 \mathrm{~g} / \mathrm{L}$ and quickly progressed up to $41 \mathrm{~g} / \mathrm{L}$. Although the serum Id level initially dropped to $35 \mathrm{~g} / \mathrm{L}$ after the first vaccine, the Id levels increased again to $47 \mathrm{~g} / \mathrm{L} 5$ weeks after the first dose despite two additional doses. Regardless of the poor clinical responses, they were able to demonstrate the adequate functional abilities of ex-vivo-generated moDCs, including uptake, processing, and presenting Id to prime T cells [120]. In order to enhance the efficacy of DC-based therapy, boosting 
strategies emerged. The addition of GM-CSF could substantially improve anti-tumor immune responses by increasing $\mathrm{T}$ cell immunity. Cull et al. showed Th1-like immune responses, which were associated with the production of IFN- $\gamma$; however, an Id-specific CTL response was absent upon DC-based therapy and GM-CSF in advanced refractory MM patients [126]. Titzer et al. tested DC-based therapy, followed by three booster events with either Id-peptides alone or Id-pulsed DCs in combination with GM-CSF in patients with advanced MM. Results showed that three out of 10 patients possessed an adequate Id-specific humoral immune response. Four out of 10 patients demonstrated a cellular immune response. Although one patient showed decreased BM MM cell infiltration, all remaining patients showed aggravation of disease [128].

A possible explanation of the poor clinical responses might be the advanced disease stage of the patients included in previous clinical trials. Alternatively, the competence of DC-based therapy in patients with early-stage/early-relapse MM was examined by Lim and colleagues. Importantly, one patient showed a $25 \%$ reduction of the serum Id level, going from $20-21 \mathrm{~g} / \mathrm{L}$ pre-vaccination to $15-17 \mathrm{~g} / \mathrm{L}$ post-vaccination. In contrast to the situation in advanced-stage MM patients, where the clinical response lasted less than five weeks [120,126,128], in early-stage MM patients, the clinical response remained for over 13 months post-DC vaccination. In addition, serum Id levels of two patients remained consistent during the follow-up of 81 months. Two patients showed disease progression two and five months post-DC vaccination [127].

While previous clinical trials included early- or advanced-relapse MM patients following various chemotherapy regimens, subsequent clinical trials examined the feasibility of Id-based DC therapy in MM patients undergoing high-dose chemotherapy and auto-HSCT. For instance, in the study of Reichardt et al., two patients were in complete remission (CR), nine were in partial remission (PR), and one had stable disease (SD) following high-dose chemotherapy and auto-HSCT. After a follow-up time of minimum 16 months post-autoHSCT, the two initial patients in CR remained in the same condition, three of the nine patients that were initially in partial remission (PR) were deceased, and the one patient in $\mathrm{SD}$ remained in SD. Moreover, the SD patient's serum Id level decreased from $2.3 \mathrm{~g} / \mathrm{dL}$ pre-vaccination to $1.8 \mathrm{~g} / \mathrm{dL}$ post-vaccination [121,131]. In the study of Liso et al., 17 of the $26 \mathrm{MM}$ patients subjected to DC-based therapy survived the follow-up time of 34 months post-auto-HSCT. Of the five patients that were in CR post-auto-HSCT, one was deceased due to PD, whereas the other four patients were still in CR. Of the 21 patients in PR postauto-HSCT, eight were deceased, whereas seven were in PR, and two were in CR [129]. Bendandi and colleagues were the first to investigate the potential of allogeneic, ex-vivogenerated moDCs pulsed with the Id. This trial included four MM patients with relapse or progressing disease who were previously subjected to reduced intensity conditioning, allogeneic HSCT, and rescue therapy with donor lymphocyte infusion. After the DC vaccination protocol, three patients had PD, whereas only one had SD [132]. Finally, Lacy et al. compared the outcome of 27 patients who had auto-HSCT followed by Id-loaded DC vaccination (APC8020; Mylovenge ${ }^{\mathrm{TM}}$ ) to that of 124 consecutive patients who only received auto-HSCT during the same period. These findings suggest that auto-HSCT followed by DC vaccination improved the overall survival by almost two years when compared to the group that missed DC-based therapy [122]. Similar conclusions were drawn by Zahradova et al., as DC-based therapy prolonged the duration of SD achieved after high-dose chemotherapy and auto-HSCT in a phase II clinical trial [125].

Yi and colleagues $[124,130]$ argued that there are several limitations concerning the DC vaccination protocol performed in previous clinical trials, including in particular the intravenous (i.v.) administration of immature moDCs [117,121,126,128,129]. Immature moDCs are at risk to differentiate into macrophages in absence of additional cytokines, and their immature state makes them less potent in activating an adequate $\mathrm{T}$ cell response. In addition, i.v. administration may reduce the potential of DCs to migrate to lymphoid tissues. Accordingly, Yi et al. reported that the immunological response was more effective in stable MM patients subjected to subcutaneous (s.c.) administered mature moDCs; however, one 
of the five participants lacked immunological responses to vaccination and showed signs of relapse [130]. Confirmed by Curti et al., s.c. administered mature DCs induced Id-specific $\mathrm{T}$ cell proliferation and $\mathrm{T}$ cell responses with high potency up to one year after DC-based therapy. In addition, they demonstrated that similar effectivity was achieved with whole Id-protein (6/15 patients) as well as with Id-VDJ-derived peptide (9/15 patients) loaded DC-based therapy [133]. An alternative injection site to improve T cell priming upon DCbased therapy is the intranodal (i.n.) route, resulting in Id-specific T and B cell responses in MM patients. Five years post-DC-based therapy, four patients remained in SD, whereas the other four patients showed PD, and one patient was lost during follow-up [124]. Another reason for the unsatisfactory immune responses could be the flawed patient selection, as the majority of the clinical trials included MM patients featuring a compromised immune system due to previous systemic treatments (e.g., high-dose chemotherapy and auto-HSCT). Röllig and colleagues were the first to report the immune effects after DC-based therapy in patients with MM clinical stage I who received no prior systemic treatment. An Id-specific $\mathrm{T}$ cell response was observed in $56 \%$ of the patients. Although specific cytokine secretion was reported, no sustainable Th1 or Th2 responses were detected. In addition, a slight decrease in the serum Id level was observed in three patients [123].

These findings suggest that the Id-protein, as MM-specific TAA, might be unqualified for inducing a proper immune response. The Id-protein may not be as immunogenic as initially thought due to their low expression on MM cells. Therefore, it should be noticed that the choice of TAA determines the efficacy of DC vaccination therapy.

\subsection{MM-Associated Antigen mRNA for DC-Based Immunotherapy}

As an alternative for Id, a broad range of MM-associated antigens have been identified. Several preclinical studies have demonstrated the potency of alternative MM-specific TAA for DC-based immunotherapy, including hTERT and MUC1 [138], heat-shock proteins [139], spermatozoa protein (sp) 17 [140] (clinicaltrials.gov identifier: NCT03591614), Dickkopf-1 (DKK1) [141], and the cancer-testis antigens melanoma-associated antigen (MAGE)-C1 (CT-7) [142] and NY-EOS-1 [143]. Currently, the MM-TAAs MAGE3, Survivin, and BCMA have been proven safe in a phase I clinical trial by Hobo et al. DC-based immunotherapy was based on matured moDCs pulsed with KLH and electroporated with mRNA of the TAA (MAGE3, Survivin, or BCMA). MM clinical stage II or III patients eligible for DCbased therapy were previously subjected to high-dose chemotherapy and auto-HSCT. Overall, TAA mRNA-loaded DC vaccination was well tolerated and was found to elicit a TAA-specific CTL response in two MM patients. After a median follow-up time of 55 months post-HSCT, 10 of the 12 patients were alive, half of whom had SD, while the other half were in PD [134]. Currently, DC loading with the Survivin antigen using an adeno-associated vector (clinicaltrials.gov identifier: NCT02851056) and DC-based therapy with Wilms Tumor 1 Gene (WT1) mRNA (clinicaltrials.gov identifier: NCT00965224) are being translated to the clinic for patients with MM. Moreover, an early phase I clinical trial, expected to start in October 2022, will study the safety and efficacy of DKK1 as MM-TAA in DC-based immunotherapy for MGUS, SMM and active MM patients (clinicaltrials.gov identifier: NCT03591614).

Further investigation into MM-specific TAAs that are abundantly expressed on MM cells is required. Cancer-testis antigens are promising targets for DC-based immunotherapy, as they are predominantly expressed on tumor cells and, to a lower extent, on healthy tissue [144]. However, a potential restriction of using a single TAA for DC-based therapy is the vulnerability to immune evasion. Tumor cells have the capacity to escape antitumor immunity by downregulation of Ags, lacking long-term clinical responses upon DC-based immunotherapy $[145,146]$.

\subsection{Total MM-Antigen Spectrum for DC-Based Immunotherapy}

Loading ex-vivo-generated moDCs with the total MM-antigen spectrum can overcome the limitations associated with the use of a single TAA for DC-based immunotherapy. Such 
an alternative source includes the fusion of moDC with patient-derived MM tumor cells using polyethylene glycol $[135,136]$. This approach enables a polyvalent immune response with the opportunity to target patient-specific neoantigens. Within this context, two clinical trials by Rosenblatt et al. have been reported $[135,136]$. Eleven patients displayed a twofold rise in $\mathrm{CD}^{+}$and $\mathrm{CD}{ }^{+} \mathrm{T}$ cell quantities, associated with disease stabilization upon DC/MM cell fusion DC-based therapy [135]. A phase II clinical trial of Rosenblatt et al. reported the therapeutic use of DC fusion vaccines in $36 \mathrm{MM}$ patients in total. This study was subdivided into two cohorts, with, on the one hand, 24 patients receiving auto-HSCT followed by a series of four DC/MM fusion vaccines at a four-week interval (cohort 1) and, on the other hand, 12 patients receiving one DC/MM fusion vaccine prior to auto-HSCT and four vaccinations post-transplantation (cohort 2). Although DC-based therapy postHSCT boosted the $\mathrm{CD}^{+}$and $\mathrm{CD}^{+}$tumor-specific $\mathrm{T}$ cell proliferation, no difference in $\mathrm{T}$ cell response was observed between patients receiving DC therapy prior to auto-HSCT and those only receiving DC therapy post-HSCT [136].

Besides DC/MM tumor cell fusion vaccines, loading DCs with tumor cell apoptotic bodies, tumor cell lysates, or total tumor RNA can provide the total MM-antigen spectrum for DC-based immunotherapy. For instance, Vasileiou and colleagues loaded ex-vivogenerated moDCs by performing two different protocols [147]. The first protocol included the uptake of apoptotic bodies from gamma-irradiated autologous myeloma cells (AMC) through phagocytosis, while in the second protocol, AMC total RNA was transfected by square-wave electroporation. In-vitro analysis showed that both protocols are efficient in priming a proper MM-specific immune response, as both $\mathrm{CD}^{+} \mathrm{T}$ cells and CD8 ${ }^{+} \mathrm{CTL}$ were expanded in numbers upon co-culture with the loaded moDCs. Although findings were mostly similar, data suggest that the RNA transfection protocol allows a higher number of antigens to be processed through the endogenous pathway instead of being cross-presented. These in-vitro results demonstrate that the use of whole tumor cell-loaded moDCs holds promise for translation into the clinic [147]. The safety and immunological efficacy of moDCs loaded with ultraviolet B-irradiated autologous dying MM cells (VAX-DC therapy) in patients with relapsed or refractory MM was reported by Jung and colleagues (clinicaltrials.gov identifier: NCT02248402) [137]. Although VAX-DC therapy favors the capturing and presentation of multiple epitopes (including potential unidentified TAAs) as well as the broad spectrum of T cell responses, the harvesting of a sufficient amount of MM cells is restricted due to previous treatments. All patients were alive after a follow-up time of 16.1 months; however, eight patients showed PD, of whom five received additional therapy [137].

In general, first- and second-generation DC vaccines are proven to be safe and feasible in MM patients, independent of the patient's clinical stage and the DC vaccination strategy. Although DC-based therapy initially provides anti-tumor immunity, long-term clinical responses are limited. Yet, a number of patients showed mild fever post-DC-based therapy. Importantly, large-scale ex-vivo moDC generation is a time-consuming and expensive process. Furthermore, ex-vivo DC differentiation requires strict compliance of the Good Manufacturing Practice (GMP) protocols and quality assurance measures [148]. Moreover, the researchers also pointed out the need for combination approaches, such as DC-based therapy accompanied by immunomodulatory agents and checkpoint inhibitors to enhance the therapeutic efficacy in MM patients. Therefore, newly improved DC-based approaches and alternative DC sources should be considered to eradicate minimal residual disease and prevent relapse of myeloma patients. 
Table 1. Overview of clinical trials using DC-based vaccination strategies in MM patients.

\begin{tabular}{|c|c|c|c|c|c|c|c|c|c|c|c|}
\hline Year & $\begin{array}{l}\text { Number of } \\
\text { Participants }\end{array}$ & $\begin{array}{l}\text { Stage of } \\
\text { Disease }\end{array}$ & $\begin{array}{c}\text { Prior } \\
\text { Treatment }\end{array}$ & $\begin{array}{c}\text { DC } \\
\text { Source }\end{array}$ & $\begin{array}{c}\text { Tumor } \\
\text { Antigen }\end{array}$ & $\begin{array}{l}\text { Antigen } \\
\text { Loading }\end{array}$ & DC Number & $\begin{array}{c}\text { Site of } \\
\text { Injection }\end{array}$ & $\begin{array}{c}\text { DC- } \\
\text { Vaccination } \\
\text { Protocol }\end{array}$ & Boosting Strategy & Ref. \\
\hline \multicolumn{12}{|c|}{ Id-loaded moDCs for DC-based immunotherapy } \\
\hline 1998 & $n=1$ & $\begin{array}{l}\text { Advanced- } \\
\text { stage } \\
\text { refractory MM }\end{array}$ & $\begin{array}{l}\text { Various chemotherapy } \\
\text { regimens }\end{array}$ & $\begin{array}{l}\text { PBMCs } \\
\text { (adherent } \\
\text { cells) }\end{array}$ & $\begin{array}{l}\text { Tumor } \\
\text { Id-proteins }\end{array}$ & $\begin{array}{l}\text { Ex-vivo-generated } \\
\text { immature moDCs were } \\
\text { loaded with Id and the } \\
\text { control vaccine with } \\
\text { KLH }\end{array}$ & $\begin{array}{c}3 \text { doses with } \\
5 \times 10^{6}, 30 \times \\
10^{6} \text { and } 45 \times \\
10^{6} \\
\text { respectively }\end{array}$ & i.v. & $\begin{array}{l}3 \text { doses at a } \\
2 \text {-week } \\
\text { interval }\end{array}$ & $\begin{array}{l}\text { No boosting } \\
\text { strategy }\end{array}$ & [120] \\
\hline 1999 & $\begin{array}{c}n=14 \\
\text { (2 declined to } \\
\text { participate) }\end{array}$ & $\begin{array}{l}\text { MM clinical } \\
\text { stage III }\end{array}$ & $\begin{array}{l}\text { High-dose } \\
\text { chemotherapy (e.g., } \\
\text { melphalan) and } \\
\text { auto-HSCT }\end{array}$ & $\begin{array}{l}\text { PBMCs } \\
\text { (precursor } \\
\text { DCs) }\end{array}$ & $\begin{array}{l}\text { Tumor } \\
\text { Id-proteins }\end{array}$ & $\begin{array}{l}\text { Ex-vivo-generated } \\
\text { immature moDCs were } \\
\text { loaded with Id }\end{array}$ & $\begin{array}{c}5.1 \times 10^{6} \pm 2.9 \\
\times 10^{6}\end{array}$ & i.v. & $\begin{array}{l}2 \text { doses at a } \\
\text { 4-week } \\
\text { interval }\end{array}$ & $\begin{array}{l}5 \text { s.c. boosts of } \\
\text { Id/KLH with } \\
\text { adjuvant, } \\
\text { administered } 4 \\
\text { weeks after the } \\
\text { second DC vaccine } \\
\text { at a } 4 \text {-week } \\
\text { interval }\end{array}$ & [121] \\
\hline 1999 & $n=2$ & $\begin{array}{l}\text { Progressive } \\
\text { refractory MM }\end{array}$ & $\begin{array}{l}\text { Chemotherapeutic } \\
\text { regimes and } \\
\text { auto-HSCT, plus (only } \\
\text { for P1) monthly i.v. } \\
\text { pamidronate treatment } \\
\text { (continuing during } \\
\text { trial) }\end{array}$ & $\begin{array}{l}\text { PBMCs } \\
\text { (adherent } \\
\text { cells) }\end{array}$ & $\begin{array}{l}\text { Tumor } \\
\text { Id-proteins }\end{array}$ & $\begin{array}{l}\text { Ex-vivo-generated } \\
\text { immature moDCs } \\
\text { were loaded with Id } \\
\text { and KLH }\end{array}$ & $\begin{array}{l}\text { P1: } 2 \text { times } 4 \times \\
10^{6} \text { and } 2 \\
\text { times } 2.5 \times 10^{7} \\
\text { P2: } 2 \text { times } 2.5 \\
\times 10^{7} \text { and } 2 \\
\text { times } 4 \times 10^{7}\end{array}$ & NS & $\begin{array}{l}4 \text { doses at a } \\
\text { 2-week } \\
\text { interval }\end{array}$ & $\begin{array}{l}\text { DC vaccination } \\
\text { followed by s.c. } \\
\text { GM-CSF }\end{array}$ & [126] \\
\hline 1999 & $n=6$ & $\begin{array}{l}\text { Early- } \\
\text { stage/early- } \\
\text { relapse } \\
\text { MM }\end{array}$ & $\begin{array}{l}\text { 3/6 patients had } \\
\text { chemotherapy and } \\
\text { dexamethasone }\end{array}$ & $\begin{array}{l}\text { PBMCs } \\
\text { (adherent } \\
\text { cells) }\end{array}$ & $\begin{array}{l}\text { Tumor } \\
\text { Id-proteins }\end{array}$ & $\begin{array}{c}\text { Ex-vivo-generated } \\
\text { immature moDCs were } \\
\text { loaded with Id and/or } \\
\text { KLH }\end{array}$ & $\begin{array}{c}3.5 \times 10^{6}-89 \times \\
10^{6}\end{array}$ & i.v. & $\begin{array}{l}5 \text { patients } \\
\text { had } 3 \text { doses, } \\
1 \text { patient } \\
\text { (P002) } 2 \\
\text { doses }\end{array}$ & $\begin{array}{l}\text { Each vaccine was } \\
\text { supported by i.v. } \\
\text { chlorpheniramine } \\
\text { treatment }\end{array}$ & [127] \\
\hline 2000 & $\begin{array}{c}n=12 \\
(n=10 \text { were } \\
\text { vaccinated })\end{array}$ & $\begin{array}{l}\text { MM clinical } \\
\text { stage II and III }\end{array}$ & Chemotherapy & $\begin{array}{l}\text { CD34+ stem } \\
\text { cells }\end{array}$ & $\begin{array}{l}\text { Tumor } \\
\text { Id-proteins }\end{array}$ & $\begin{array}{l}\text { Ex-vivo-generated } \\
\text { immature moDCs were } \\
\text { loaded with Id }\end{array}$ & $\begin{array}{c}1 \times 10^{6}-4 \times \\
10^{7}\end{array}$ & s.c. & 1 dose & $\begin{array}{c}3 \text { boosts of } \\
\text { Id-proteins and } \\
\text { GM-CSF }(9 / 11) \text { or } \\
\text { with Id-loaded } \\
\text { DCs }(2 / 11)\end{array}$ & [128] \\
\hline
\end{tabular}


Table 1. Cont.

\begin{tabular}{|c|c|c|c|c|c|c|c|c|c|c|c|}
\hline Year & $\begin{array}{l}\text { Number of } \\
\text { Participants }\end{array}$ & $\begin{array}{l}\text { Stage of } \\
\text { Disease }\end{array}$ & $\begin{array}{c}\text { Prior } \\
\text { Treatment }\end{array}$ & $\begin{array}{c}\text { DC } \\
\text { Source }\end{array}$ & $\begin{array}{c}\text { Tumor } \\
\text { Antigen }\end{array}$ & $\begin{array}{l}\text { Antigen } \\
\text { Loading }\end{array}$ & DC Number & $\begin{array}{c}\text { Site of } \\
\text { Injection }\end{array}$ & $\begin{array}{c}\text { DC- } \\
\text { Vaccination } \\
\text { Protocol }\end{array}$ & Boosting Strategy & Ref. \\
\hline 2000 & $n=26$ & $\begin{array}{l}\text { MM clinical } \\
\text { stage IIA }\end{array}$ & $\begin{array}{c}\text { High-dose } \\
\text { chemotherapy and } \\
\text { auto-HSCT }\end{array}$ & PBMCs & $\begin{array}{c}\text { Tumor } \\
\text { Id-proteins }\end{array}$ & $\begin{array}{l}\text { DCs were cultured } \\
\text { with either Id or with } \\
\text { Id-KLH conjugates }\end{array}$ & $\begin{array}{c}\text { First } 12 \\
\text { patients: } \\
3.0-19.1 \times 10^{6} \\
\text { Other } 14 \\
\text { patients: } \\
21.1-511.7 \times \\
10^{6}\end{array}$ & i.v. & $\begin{array}{c}12 \text { patients } \\
\text { received } 2 \\
\text { doses of } \\
\text { Id-loaded } \\
\text { DCs; } 14 \\
\text { patients } \\
\text { received } 2 \\
\text { doses of DCs } \\
\text { loaded with } \\
\text { Id/KLH }\end{array}$ & $\begin{array}{l}5 \text { s.c. boosts of } \\
\text { Id-KLH conjugates } \\
\text { at a } 4 \text {-week } \\
\text { interval }\end{array}$ & [129] \\
\hline 2002 & $n=5$ & $\begin{array}{l}\text { Patients are } \\
\text { stable or in } \\
\text { partial } \\
\text { remission }\end{array}$ & $\begin{array}{c}\text { High-dose } \\
\text { chemotherapy and } \\
\text { auto-HSCT }\end{array}$ & $\begin{array}{l}\text { PBMCs } \\
\text { (adherent } \\
\text { cells) }\end{array}$ & $\begin{array}{l}\text { Tumor } \\
\text { Id-proteins }\end{array}$ & $\begin{array}{l}\text { Ex-vivo-generated } \\
\text { immature moDCs were } \\
\text { loaded with Id and } \\
\text { then matured }\end{array}$ & $20 \times 10^{7}$ & s.c. & $\begin{array}{l}3 \text { doses at a } \\
\text { 2-week } \\
\text { interval }\end{array}$ & $\begin{array}{c}\text { Low-dose of } \\
\text { recombinant IL-2 } \\
\text { was given s.c. for } 5 \\
\text { days following } \\
\text { each vaccination } \\
\end{array}$ & [130] \\
\hline 2003 & $n=12$ & $\begin{array}{l}\text { MM clinical } \\
\text { stage II and III }\end{array}$ & $\begin{array}{c}\text { High-dose } \\
\text { chemotherapy } \\
\text { and auto-HSCT }\end{array}$ & $\begin{array}{l}\text { PBMCs } \\
\text { (adherent } \\
\text { cells) }\end{array}$ & $\begin{array}{l}\text { Tumor } \\
\text { Id-proteins }\end{array}$ & $\begin{array}{l}\text { Ex-vivo-generated } \\
\text { immature moDCs were } \\
\text { loaded with Id and } \\
\text { then matured }\end{array}$ & $\begin{array}{c}\text { Median of } \\
4.5 \times 10^{6} \mathrm{DCs} \\
\text { were obtained }\end{array}$ & i.v. & $\begin{array}{l}2 \text { doses: at } \\
\text { day } 0 \text { and } \\
\text { day } 15\end{array}$ & $\begin{array}{l}\text { 10/12 patients had } \\
5 \text { s.c. Id/KLH } \\
\text { booster } \\
\text { immunizations (at } \\
\text { a 4-week interval) } \\
\text { co-injected with } \\
\text { GM-CSF (for } 3 \\
\text { consecutive days) }\end{array}$ & [131] \\
\hline 2006 & $n=4$ & $\begin{array}{l}\text { Patients with } \\
\text { relapse or } \\
\text { progressing } \\
\text { disease }\end{array}$ & $\begin{array}{l}\text { Reduced intensity } \\
\text { conditioning, } \\
\text { allogeneic HSCT, and } \\
\text { rescue therapy with } \\
\text { donor lymphocyte } \\
\text { infusion }\end{array}$ & $\begin{array}{c}\text { PBMCs } \\
\text { (monocytes, } \\
(\text { CD14 + )) }\end{array}$ & $\begin{array}{l}\text { Tumor } \\
\text { Id-proteins }\end{array}$ & $\begin{array}{c}\text { Allogeneic } \\
\text { ex-vivo-generated } \\
\text { moDCs loaded with Id } \\
\text { (maturation state of } \\
\text { DCs: NS) }\end{array}$ & $5-10 \times 10^{8}$ & Intra-dermal & $\begin{array}{c}3 \text { cycles, } \\
\text { each with } 3 \\
\text { doses. Cycle } \\
\text { 1: } 3 \text { doses at } \\
\text { a } 4 \text {-week } \\
\text { interval } \\
\text { Cycle 2: } 3 \\
\text { doses at a } \\
\text { 8-week } \\
\text { interval } \\
\text { Cycle 3: } 3 \\
\text { doses at a } \\
\text { 12-week } \\
\text { interval }\end{array}$ & $\begin{array}{l}\text { Each dose was } \\
\text { accompanied by } \\
\text { the s.c. } \\
\text { administration of } \\
\text { Id-proteins } \\
\text { conjugated with } \\
\text { KLH in } \\
\text { combination with } \\
\text { GM-CSF }\end{array}$ & [132] \\
\hline
\end{tabular}


Table 1. Cont.

\begin{tabular}{|c|c|c|c|c|c|c|c|c|c|c|c|}
\hline Year & $\begin{array}{l}\text { Number of } \\
\text { Participants }\end{array}$ & $\begin{array}{l}\text { Stage of } \\
\text { Disease }\end{array}$ & $\begin{array}{c}\text { Prior } \\
\text { Treatment }\end{array}$ & $\begin{array}{c}\text { DC } \\
\text { Source }\end{array}$ & $\begin{array}{c}\text { Tumor } \\
\text { Antigen }\end{array}$ & $\begin{array}{l}\text { Antigen } \\
\text { Loading }\end{array}$ & DC Number & $\begin{array}{c}\text { Site of } \\
\text { Injection }\end{array}$ & $\begin{array}{c}\text { DC- } \\
\text { Vaccination } \\
\text { Protocol }\end{array}$ & Boosting Strategy & Ref. \\
\hline 2007 & $n=15$ & $\begin{array}{l}\text { MM clinical } \\
\text { stage IA } \\
(8 / 15), \text { IIA } \\
(2 / 15), \text { IIIA } \\
(5 / 15)\end{array}$ & $\begin{array}{c}\text { High-dose } \\
\text { chemotherapy, } \\
\text { followed by } \\
\text { auto-HSCT and } \\
\text { maintenance therapy }\end{array}$ & $\begin{array}{c}\text { PBMCs } \\
\text { (monocytes, } \\
(\text { CD14+)) }\end{array}$ & $\begin{array}{c}\text { Tumor } \\
\text { VDJ-derived } \\
\text { peptides or } \\
\text { whole } \\
\text { protein }\end{array}$ & $\begin{array}{c}\text { Ex-vivo-generated } \\
\text { immature moDCs were } \\
\text { loaded with } \\
\text { VDJ-derived peptides } \\
(9 / 15) \text { or with whole } \\
\text { protein }(6 / 15) \text { and } \\
\text { KLH and then matured }\end{array}$ & $\begin{array}{c}3 \text { s.c. doses: } 5 \\
\times 10^{6}, 10 \times \\
10^{6}, \text { and } 50 \times \\
10^{6} \\
2 \text { i.v. doses: } 10 \\
\times 10^{6} \text { and } 50 \\
\times 10^{6}\end{array}$ & s.c./i.v. & $\begin{array}{l}3 \text { s.c. doses } \\
\text { and } 2 \text { i.v. } \\
\text { doses at a } \\
\text { 2-week } \\
\text { interval }\end{array}$ & $\begin{array}{l}3 \text { patients received } \\
\text { additional s.c. } \\
\text { injections of } 50 \times \\
10^{6} \mathrm{DCs} \text {, monthly, } \\
\text { in case of stable } \\
\text { disease and DC } \\
\text { availability }\end{array}$ & [133] \\
\hline 2010 & $n=9$ & $\begin{array}{c}\text { SMM }(8 / 9) \\
\text { and SD post } \\
\text { auto-HSCT } \\
(1 / 9)\end{array}$ & $\begin{array}{c}\text { No prior treatment } \\
(8 / 9) \text { and auto-HSCT } \\
(1 / 9)\end{array}$ & $\begin{array}{l}\text { PBMC } \\
\text { (adherent } \\
\text { cells) }\end{array}$ & $\begin{array}{l}\text { Tumor } \\
\text { Id-proteins }\end{array}$ & $\begin{array}{l}\text { Ex-vivo-generated } \\
\text { immature moDCs were } \\
\text { loaded with Id and } \\
\text { KLH and then matured }\end{array}$ & $\begin{array}{c}\text { Median } \\
11-13.5 \times 10^{6}\end{array}$ & i.n. & $\begin{array}{l}4 \text { doses at a } \\
\text { 1-week } \\
\text { interval }\end{array}$ & $\begin{array}{l}\text { S.c. recombinant } \\
\text { IL-2 for } 5 \\
\text { consecutive days } \\
\text { following each DC } \\
\text { vaccination }\end{array}$ & [124] \\
\hline 2012 & $\begin{array}{c}n=25 \\
(11 / 25 \\
\text { participants } \\
\text { were } \\
\text { vaccinated, } \\
13 / 25 \text { were in } \\
\text { the control } \\
\text { group, } 1 / 25 \\
\text { was excluded) }\end{array}$ & $\begin{array}{c}\text { MM clinical } \\
\text { stage I: } 4 / 11 \\
\text { and } 4 / 13 \\
\text { stage II: } 3 / 11 \\
\text { and } 3 / 13 \\
\text { stage III: } 4 / 11 \\
\text { and } 6 / 13\end{array}$ & $\begin{array}{c}\text { Vaccinated group: } \\
\text { auto-HSCT }(9 / 11), 2 \\
\text { auto-HSCT }(1 / 11), \\
\text { vaccination with } \\
\text { Id-proteins coupled } \\
\text { with KLH }(3 / 11)\end{array}$ & PBMC & $\begin{array}{l}\text { Tumor } \\
\text { Id-proteins }\end{array}$ & $\begin{array}{l}\text { Ex-vivo-generated } \\
\text { immature moDCs were } \\
\text { loaded with Id and } \\
\text { then matured }\end{array}$ & $\begin{array}{c}\text { Median of } 6.4 \\
\times 10^{6} \mathrm{DCs} \\
\text { were obtained }\end{array}$ & Intradermal & $\begin{array}{l}6 \text { doses at a } \\
\text { 4-week } \\
\text { interval }\end{array}$ & $\begin{array}{l}\text { No boosting } \\
\text { strategy }\end{array}$ & [125] \\
\hline \multicolumn{12}{|c|}{ MM-TAA mRNA-loaded moDCs for DC-based immunotherapy } \\
\hline 2013 & $n=12$ & $\begin{array}{l}\text { MM clinical } \\
\text { stage II and III }\end{array}$ & $\begin{array}{l}\text { High-dose } \\
\text { chemotherapy (e.g., } \\
\text { melphalan) and } \\
\text { auto-HSCT }\end{array}$ & $\begin{array}{c}\text { PBMC } \\
\text { (adherent } \\
\text { cells) }\end{array}$ & $\begin{array}{l}\text { TAA-mRNA } \\
\text { (MAGE3, } \\
\text { Survivin or } \\
\text { BCMA) }\end{array}$ & $\begin{array}{c}\text { Ex-vivo-generated } \\
\text { immature moDCs were } \\
\text { loaded with KLH and } \\
\text { electroporated with } \\
\text { TAA-mRNA and then } \\
\text { matured }\end{array}$ & $\begin{array}{c}5-23 \times 10^{6} \\
(\text { i.v. }) \\
8-12 \times 10^{6} \\
\text { (Intradermal) }\end{array}$ & $\begin{array}{c}\text { i.v./ } \\
\text { Intradermal }\end{array}$ & $\begin{array}{l}3 \text { doses at a } \\
\text { 2-week } \\
\text { interval (P1 } \\
\text { and } \mathrm{P} 3 \text { were } \\
\text { revacci- } \\
\text { nated) }\end{array}$ & $\begin{array}{l}\text { No boosting } \\
\text { strategy }\end{array}$ & [134] \\
\hline
\end{tabular}


Table 1. Cont.

\begin{tabular}{|c|c|c|c|c|c|c|c|c|c|c|c|}
\hline Year & $\begin{array}{l}\text { Number of } \\
\text { Participants }\end{array}$ & $\begin{array}{l}\text { Stage of } \\
\text { Disease }\end{array}$ & $\begin{array}{c}\text { Prior } \\
\text { Treatment }\end{array}$ & $\begin{array}{c}\text { DC } \\
\text { Source }\end{array}$ & $\begin{array}{c}\text { Tumor } \\
\text { Antigen }\end{array}$ & $\begin{array}{l}\text { Antigen } \\
\text { Loading }\end{array}$ & DC Number & $\begin{array}{c}\text { Site of } \\
\text { Injection }\end{array}$ & $\begin{array}{c}\text { DC- } \\
\text { Vaccination } \\
\text { Protocol }\end{array}$ & Boosting Strategy & Ref. \\
\hline \multicolumn{12}{|c|}{ Total MM-antigen spectrum-loaded moDCs for DC-based immunotherapy } \\
\hline 2011 & $\begin{array}{l}\quad n=18 \\
\text { (1 patient was } \\
\text { excluded due } \\
\text { to inadequate } \\
\text { cell yields for } \\
\text { vaccination) }\end{array}$ & $\begin{array}{l}\text { All patients } \\
\text { show signs of } \\
\text { active disease, } \\
2 / 18 \text { patients } \\
\text { have MM } \\
\text { clinical stage I }\end{array}$ & $\begin{array}{l}\text { 14/18 had high-dose } \\
\text { chemotherapy and } \\
\text { auto-HSCT } \\
\text { 2/18 received no prior } \\
\text { therapy }\end{array}$ & $\begin{array}{l}\text { PBMC } \\
\text { (adherent } \\
\text { cells) }\end{array}$ & $\begin{array}{l}\text { Tumor MM } \\
\text { cells }\end{array}$ & $\begin{array}{l}\text { Ex-vivo-generated } \\
\text { immature moDCs were } \\
\text { co-cultured with MM } \\
\text { tumor cells at a } 3: 1 \text { to } \\
\text { 10:1 ratio and then } \\
\text { matured }\end{array}$ & $\begin{array}{c}1 \times 10^{6}-4 \times \\
10^{6} \text { fusion cells }\end{array}$ & s.c. & $\begin{array}{c}3 \text { doses at a } \\
\text { 3-week } \\
\text { interval }\end{array}$ & $\begin{array}{c}\text { DC vaccination } \\
\text { was accompanied } \\
\text { by s.c. boosts of } \\
\text { GM-CSF } \\
\text { administered at } \\
\text { the vaccination site } \\
\text { for } 4 \text { consecutive } \\
\text { days }\end{array}$ & [135] \\
\hline \multirow[t]{2}{*}{2013} & $\begin{array}{c}\text { Cohort } 1 \\
n=26 \\
\text { (24/26 were } \\
\text { vaccinated) } \\
\end{array}$ & \multirow{2}{*}{$\begin{array}{c}\text { No clinical } \\
\text { stage specified, } \\
\text { patients had a } \\
\text { median of } 55 \% \\
\text { plasma cells in } \\
\text { BM at } \\
\text { enrollment }\end{array}$} & \multirow{2}{*}{$\begin{array}{l}24 \text { patients had } \\
\text { bortezomib-based } \\
\text { regimen, } 7 \\
\text { lenalidomide-based } \\
\text { regimen, } 11 \\
\text { thalidomide-based } \\
\text { regimen, and } 11 \\
\text { lenalidomide--, } \\
\text { bortezomib-, and } \\
\text { dexamethasone-based } \\
\text { regimen }\end{array}$} & \multirow[t]{2}{*}{$\begin{array}{l}\text { PBMC } \\
\text { (adherent } \\
\text { cells) }\end{array}$} & \multirow[t]{2}{*}{$\begin{array}{l}\text { Tumor MM } \\
\text { cells }\end{array}$} & \multirow{2}{*}{$\begin{array}{l}\text { Ex-vivo-generated } \\
\text { immature moDCs were } \\
\text { co-cultured with MM } \\
\text { tumor cells and then } \\
\text { matured }\end{array}$} & \multirow[t]{2}{*}{$\begin{array}{l}3.6 \times 10^{6} \\
\text { fusion cells }\end{array}$} & \multirow[t]{2}{*}{ s.c. } & $\begin{array}{l}3 \text { doses post- } \\
\text { auto-HSCT } \\
\text { at a } 4 \text {-week } \\
\text { interval }\end{array}$ & \multirow{2}{*}{$\begin{array}{c}\text { DC vaccination } \\
\text { was accompanied } \\
\text { by s.c. boosts of } \\
\text { GM-CSF } \\
\text { administered at } \\
\text { the vaccine site for } \\
4 \text { consecutive days }\end{array}$} & \multirow[t]{2}{*}{ [136] } \\
\hline & $\begin{array}{c}\text { Cohort } 2 \\
n=19 \\
(12 / 19 \text { were } \\
\text { vaccinated })\end{array}$ & & & & & & & & $\begin{array}{l}1 \text { dose prior } \\
\text { to stem cell } \\
\text { mobiliza- } \\
\text { tion; } 3 \text { doses } \\
\text { post-auto- } \\
\text { HSCT at a } \\
\text { 4-week } \\
\text { interval }\end{array}$ & & \\
\hline 2017 & $\begin{array}{c}n=16 \\
(n=12 \text { were } \\
\text { vaccinated) }\end{array}$ & $\begin{array}{l}\text { MM clinical } \\
\text { stage I }(2 / 12) \\
\text { MM clinical } \\
\text { stage II }(5 / 12) \\
\text { MM clinical } \\
\text { stage III }(5 / 12)\end{array}$ & $\begin{array}{l}\text { All patients had } \\
\text { thalidomide and } \\
\text { bortezomib therapy. } \\
9 \text { patients had } \\
\text { high-dose } \\
\text { chemotherapy and } \\
\text { auto-HSCT; } 2 \text { had } \\
\text { tandem auto-HSCT }\end{array}$ & $\begin{array}{l}\text { PBMC } \\
\text { (adherent } \\
\text { cells) }\end{array}$ & $\begin{array}{c}\text { UVB } \\
\text { irradiated } \\
\text { tumor MM } \\
\text { cells }\end{array}$ & $\begin{array}{c}\text { VAX-DC/MM: } \\
\text { immature moDCs were } \\
\text { loaded with UVB } \\
\text { irradiated dying } \\
\text { autologous MM cells } \\
\text { and KLH and then } \\
\text { matured }\end{array}$ & $\begin{array}{c}5 \times 10^{6} \text { or } 10 \\
\times 10^{6}\end{array}$ & Intradermal & $\begin{array}{l}4 \text { doses at a } \\
1 \text {-week } \\
\text { interval }\end{array}$ & $\begin{array}{c}3 \text { days prior to } \\
\text { VAX-DC } / \mathrm{MM} \\
\text { injection, cy- } \\
\text { clophosphamide } \\
\text { was i.v. } \\
\text { administered }\end{array}$ & [137] \\
\hline
\end{tabular}




\section{Opportunities and Future Directions for DC-Based Immunotherapy in MM}

\subsection{Combination Strategies to Enhance the Efficacy of DC-Based Immunotherapy in MM}

To pursue the maximum potential of DC-based therapies, increasing attention is being paid to combining DC-based immunotherapies with conventional therapies, including chemotherapy, immunomodulatory drugs (IMiDs; lenalidomide and pomalidomide) and immune checkpoint inhibitors (ICIs). Combination strategies optimizing the efficacy of DC-based therapy, mainly in solid tumors, have been reviewed extensively elsewhere. In summary, promising combination therapies with chemotherapy, radiotherapy, and ICIs are under investigation in several (pre)clinical cancer models [94,149]. Here, the main focus concerns combination therapies for MM, as summarized in Table 2.

MM features a suppressive tumor microenvironment that fosters tumor growth, immune escape, and drug resistance [22,23]. Immune-suppressive cells, such as Tregs, TAMs, and MDSCs, and immune inhibitory pathways, including the programmed death-1 (PD-1)/programmed death-ligand 1 (PD-L1) pathway and the cytotoxic T lymphocyteassociated protein 4 (CTLA-4) pathway, could hamper DC-based immunotherapy, causing insufficient clinical responses in MM [150]. Therefore, combination strategies, including agents targeting the immunosuppressive microenvironment, may strongly improve clinical responses to DC-based immunotherapy in patients with MM.

Given that the inhibitory signals PD-L1 and PD-1 are strongly expressed on ex-vivogenerated moDCs fused with autologous MM cells and on CD4+ and CD8+ T cells derived from patients with advanced $\mathrm{MM}$, respectively, this may be a reason for the unsatisfactory immune responses after DC/MM fusion vaccination as previously described [151]. PD-L1 is associated with a dysfunctional $\mathrm{T}$ cell phenotype and may potentially contribute to Treg inflation, disrupting the activation of an adequate $\mathrm{T}$ cell immune response following the DC/MM fusion vaccine [150]. Rosenblatt et al. blocked PD-1 signaling using the anti-PD-1 antibody CT-011 in a preclinical MM mouse model, showing improved activated $\mathrm{T}$ cell responses following DC/MM fusion vaccination [151]. Two clinical trials that are currently ongoing and combine DC vaccination and PD-1 blockade are (1) a clinical trial including MM patients undergoing serial infusions of pidilizumab (CT-011) in conjunction with DC/MM fusion vaccination following auto-HSCT (clinicaltrials.gov identifier: NCT01067287) and (2) a phase II clinical trial subjecting relapsed MM patients to DC/MM fusion vaccination in combination with another PD-1 blocker, nivolumab (clinicaltrials.gov identifier: NCT03782064) (Table 2). Luptakova et al. indicated the potential of the immunomodulating drug, lenalidomide, to support DC/MM fusion vaccination, as it boosts $\mathrm{T}$ cell proliferation and downgrades inhibitory factors, such as Tregs and PD-1 expression [152]. Furthermore, preclinical MM mouse models subjected to dying MM cell-loaded DC therapy in combination with anti-PD-1 alone, lenalidomide alone, or lenalidomide joined by PD-1 blockade strongly improved DC-induced immune responses when compared to solo-DC-based therapy [153]. Moreover, prolonged survival was observed after triple combination therapy (DC therapy, lenalidomide, and anti-PD-1) in the murine MM model. Similar results were obtained when combining dying MM cell-loaded DC therapy with pomalidomide and dexamethasone [154]. The most promising prognosis in a preclinical MM model was obtained after quadruple combination therapy, including dying MM cell-loaded DC therapy, pomalidomide, dexamethasone, and anti-PD-1 therapy [155]. In this regard, a phase II clinical trial is currently being performed, examining the therapeutic potential of combining lenalidomide and DC/MM fusion vaccination in MM patients previously subjected to auto-HSCT (clinicaltrials.gov identifier: NCT02728102) (Table 2). In summary, DC-based therapies supported by ICIs or IMiDs may increase the anti-MM immunity by suppressing immunosuppressive cells and inhibitory signals and activating effector cells.

\subsection{A New Upcoming DC Source for DC-Based Immunotherapy}

In MM, clinical trials have been conducted with first-generation and second-generation DC vaccines, both depending on MM patient-derived ex-vivo-generated moDCs. The 
compromised functionality of ex-vivo-generated moDCs is put forward as one of the main reasons for their unsatisfactory therapeutic efficacy, as sufficient immune responses cannot be achieved in clinical trials $[20,21,109]$. Therefore, evaluating the phenotypical and functional characteristics of these DCs is fundamental to identify the factors contributing to their limited success. Shinde and colleagues generated moDCs from MM patients samples (MM-DCs) and examined them in parallel with moDCs generated from healthy donor samples (HD-DCs) [100]. MM samples contained a less pronounced precursor population (adherent mononuclear cells; CD14 ${ }^{+}$monocytes), which indicates a significantly lower moDC yield when compared to HD samples. However, both MM-DCs and HDDCs showed a mature phenotype and showed equivalent Ag uptake and allogeneic $\mathrm{T}$ cell activation. By contrast, the migratory capacity to the lymph node, and the secretion capacity of crucial cytokines (e.g., IL12p70) were less pronounced in moDCs derived from MM patients, making MM-DCs not as potent in inducing an anti-MM response as HD-DC. Another explanation for defective DCs in MM patients could be the immunosuppressive activity of MM cells and the suppressive tumor microenvironment as cited earlier in this review.

These findings suggest that ex-vivo-generated moDCs derived from MM patients are not the most convenient DC source for DC-based immunotherapy. Alternative sources are being investigated, including the differentiation of DCs from human pluripotent stem cells (hPSCs) $[119,156]$. Shinde et al. compared stem cell-derived DCs from MM patients (MMSC-DCs) with those from healthy individuals (HD-SC-DCs) [157]. Besides a similar SC-DC yield, both MM-SC-DCs and HD-SC-DCs exhibited a mature DC cell-surface phenotype. In contrast to moDCs generated from MM samples with impaired migration capabilities and CCR7 expression, SC-DCs showed efficient migration abilities towards CCL-19. This may be due to the fact that DCs generated from SCs, regardless of HD or MM samples, adequately express CCR7 and feature a lower autocrine IL-6 secretion. This study implies the use of HSC as a source for large numbers of functional DCs. In addition, great attention has been given to the in-depth characterization of tissue-derived DC subsets in cancer, in particular the $\mathrm{CDC}$ subset(s), aiming to identify additional DC sources with superior features for DC-based immunotherapy. Based on these findings, a new DC source for DC-based immunotherapy is on the rise to kick-start the development of next-generation DC vaccines. Naturally occurring, tissue-derived DCs pose two major advantages over ex-vivo-generated moDCs, including superior functionality and reduced culturing time and costs [145]. Previous findings of our research group showed that both $\mathrm{CDC} 1$ and cDC2 subsets were able to elicit therapeutically relevant immune responses in cancer [98]. Mice vaccinated with tumor-derived $\mathrm{cDC} 1$ s could efficiently activate $\mathrm{CD} 8^{+} \mathrm{T}$ cells and confer protection in tumor models in which immunosuppressive cells are present in very low numbers. Importantly, cDC2 vaccination could efficiently activate Th17 cells and led to reduced tumor growth in tumors with a strong immunosuppressive immune compartment. Moreover, next-generation $\mathrm{DC}$ vaccines using the $\mathrm{CDC} 2\left(\mathrm{CD} 1 \mathrm{c}^{+} / \mathrm{BDCA}^{+}\right)$subset have been proven safe and feasible, with promising clinical responses, indicating the ability of combined modality treatment in patients with advanced-stage metastatic prostate cancer and patients with stage IV metastatic melanoma [158,159]. 
Table 2. Overview of clinical trials using DC-based combination strategies in MM patients.

\begin{tabular}{|c|c|c|c|c|c|c|c|c|}
\hline Study Start Year & NCT Number & $\begin{array}{c}\text { Clinical } \\
\text { Trial }\end{array}$ & $\begin{array}{l}\text { Number of } \\
\text { Participants }\end{array}$ & $\begin{array}{c}\text { Prior } \\
\text { Treatment }\end{array}$ & $\begin{array}{c}\text { Tumor } \\
\text { Antigen }\end{array}$ & $\begin{array}{c}\text { DC-Based } \\
\text { Vaccination } \\
\text { Strategy }\end{array}$ & $\begin{array}{c}\text { Combination } \\
\text { Therapy }\end{array}$ & Treatment Protocol \\
\hline 2010 & NCT01067287 & Phase II & $n=35$ & Auto-HSCT & Tumor MM cells & $\begin{array}{l}\mathrm{DC} / \mathrm{MM} \text { fusion } \\
\text { vaccine }\end{array}$ & $\begin{array}{l}\text { The monoclonal } \\
\text { antibody; } \\
\text { CT-011 }\end{array}$ & $\begin{array}{l}3 \text { doses of CT-011 at a 6-week } \\
\text { interval, starting } 1-3 \text { months } \\
\text { following auto-HSCT } \\
\text { DC/MM fusion vaccine was } \\
\text { given } 1 \text { week following each } \\
\text { infusion of CT-011 }\end{array}$ \\
\hline
\end{tabular}

DC, dendritic cell; MM, multiple myeloma; auto-HSCT, autologous hematopoietic stem-cell transplantation; GM-CSF, granulocyte-macrophage colony-stimulating factor; IMiDs, immunomodulatory drugs; PI, proteasome inhibitor. 


\subsection{Timing of DC-Based Immunotherapy}

The majority of the clinical trials examining the therapeutic efficacy of first- and secondgeneration DC vaccines have been performed in heavily treated, advanced-stage MM patients. There are studies arguing that the limited therapeutic efficacy of DC-based therapy is due to the compromised immune system, which is found in refractory and relapsed MM patients previously treated with systemic therapies [123]. High-dose chemotherapy and auto-HSCT allow fast hematopoietic recovery and prolong the period of remission compared to standard chemotherapy. Unfortunately, complete remission and total eradication of the disease is rarely achieved. Therefore, DC-based therapy and adoptive T cell therapy in those lymphopenic MM patients may be an added value to eradicate minimal residual disease and restore the patient's immune competence [160]. The period of post-transplant lymphopoietic reconstitution is associated with enhanced responsiveness to cancer vaccines due to the depletion of inhibitory cell types, such as Tregs, that mediate tumor-associated tolerance. Furthermore, DC-based immunotherapy supported by the IMiD lenalidomide that targets the tumor microenvironment has been shown to improve clinical outcomes in MM patients who may or may not have been previously subjected to auto-HSCT [151,152]. Therefore, DC-based therapy is a particularly attractive option for MM patients undergoing auto-HSCT or patients in remission to specifically eliminate residual cancer cells and protect against relapses.

\section{Concluding Remarks}

DC-based immunotherapy has been proven to be a safe and tolerable therapeutic approach with the potential to induce clinical responses in MM patients. However, thus far, clinical responses have been inconsistent in clinical trials using first- and second-generation DC vaccines. In this regard, the limited success may partially be due to the used DC source, as ex-vivo-generated moDCs have limited functional abilities. Another explanation is related to the strong immunodeficient signature of MM patients, as both the MM cells and the tumor microenvironment can hamper proper DC differentiation, maturation, and activation. Advanced perspectives in DC biology allow the rise of new potential DC sources. For instance, tissue-derived DC subsets with superior features for DC-based immunotherapy can provide the foundation for next-generation DC vaccination in MM. Most importantly, combining DC-based therapy with therapies targeting the suppressive microenvironment (e.g., IMiDs and ICIs) as well as other therapies, such as chemotherapy, aims to improve the quality of anti-tumor immune responses and the clinical outcome in patients with MM. This is especially true for early-stage MM patients or MM patients in partial or complete remission, where treatment with DC-based immunotherapy can provide sustained remission and prevent or delay relapse.

Author Contributions: Conceptualization, E.V., D.L. and K.D.V.; validation, E.V., J.B.M., S.D., G.R., A.M., E.D.B., E.M., K.V., D.L. and K.D.V.; investigation, E.V.; writing—original draft preparation, E.V.; writing-review and editing, E.V., D.L. and K.D.V.; visualization, E.V. and J.B.M.; supervision, D.L. and K.D.V.; funding acquisition, E.V., S.D., D.L. and K.D.V. All authors have read and agreed to the published version of the manuscript.

Funding: E.V. is financially supported by the Award Cancer Research-Oncology Center Vrije Universiteit Brussel, funded by the bequests of late Ms. Esther Desmedt and late Ms. Irma Noë. S.D. is supported by Stichting tegen Kanker (2021-023). D.L. is supported by grants from FWO (12Z1820N), Kom op Tegen Kanker (VUB/2018/11558/1), Stichting tegen Kanker (F/2020/1418), and Vrije Universiteit Brussel. K.D.V is supported by the VUB spearhead research programs (SRP48) and FWO (12I0921N).

Institutional Review Board Statement: Not applicable.

Informed Consent Statement: Not applicable.

Data Availability Statement: The data presented in this study are available in the article and original works.

Conflicts of Interest: The authors declare no conflict of interest. 


\section{References}

1. Röllig, C.; Knop, S.; Bornhäuser, M. Multiple myeloma. Lancet 2015, 385, 2197-2208. [CrossRef]

2. Bergenbrant, S.; Yi, Q.; Österborg, A.; Björkholm, M.; Ösby, E.; Mellstedt, H.; Lefvert, A.K.; Holm, G. Modulation of anti-idiotypic immune response by immunization with the autologous M-component protein in multiple myeloma patients. Br. J. Haematol. 1996, 92, 840-846. [CrossRef]

3. García-Ortiz, A.; Rodríguez-García, Y.; Encinas, J.; Maroto-Martín, E.; Castellano, E.; Teixidó, J.; Martínez-López, J. The role of tumor microenvironment in multiple myeloma development and progression. Cancers 2021, 13, 217. [CrossRef]

4. Palumbo, A.; Anderson, K. Multiple Myeloma. N. Engl. J. Med. 2011, 364, 1046-1060. [CrossRef]

5. Kazandjian, D. Multiple myeloma epidemiology and survival: A unique malignancy. Semin Oncol. 2016, 43, 676-681. [CrossRef]

6. Parrondo, R.D.; Ailawadhi, S.; Sher, T.; Chanan-Khan, A.A.; Roy, V. Autologous Stem-Cell Transplantation for Multiple Myeloma in the Era of Novel Therapies. JCO Oncol. Pract. 2020, 16, 56-66. [CrossRef]

7. Dingli, D.; Ailawadhi, S.; Bergsagel, P.L.; Buadi, F.K.; Dispenzieri, A.; Fonseca, R.; Gertz, M.A.; Gonsalves, W.I.; Hayman, S.R.; Kapoor, P.; et al. Therapy for Relapsed Multiple Myeloma: Guidelines from the Mayo Stratification for Myeloma and Risk-Adapted Therapy. Mayo Clin. Proc. 2017, 92, 578-598. [CrossRef]

8. Zanwar, S. Immune-based therapies in the management of multiple myeloma. Blood Cancer J. 2020, 10, 84. [CrossRef]

9. Rasche, L.; Wäsch, R.; Munder, M.; Goldschmidt, H.; Raab, M.S. Novel immunotherapies in multiple myeloma-Chances and challenges. Haematologica 2021, 106, 2555-2565. [CrossRef]

10. Radocha, J.; van de Donk, N.W.C.J.; Weisel, K. Monoclonal antibodies and antibody drug conjugates in multiple myeloma. Cancers 2021, 13, 1571. [CrossRef]

11. Podar, K.; Leleu, X. Relapsed/Refractory Multiple Myeloma in 2020/2021 and Beyond. Cancers 2021, 13, 5154. [CrossRef] [PubMed]

12. Ghobrial, I.; Cruz, C.H.; Garfall, A.; Shah, N.; Munshi, N.; Kaufman, J.; Boise, L.H.; Morgan, G.; Adalsteinsson, V.A.; Manier, S.; et al. Immunotherapy in Multiple Myeloma: Accelerating on the Path to the Patient. Clin. Lymphoma Myeloma Leuk. 2019, 19, 332-344. [CrossRef]

13. Yamamoto, L.; Amodio, N.; Gulla, A.; Anderson, K.C. Harnessing the Immune System Against Multiple Myeloma: Challenges and Opportunities. Front. Oncol. 2021, 10, 3160. [CrossRef]

14. Romano, A.; Conticello, C.; Cavalli, M.; Vetro, C.; La Fauci, A.; Parrinello, N.L.; Di Raimondo, F. Immunological dysregulation in multiple myeloma microenvironment. BioMed Res. Int. 2014, 2014, 198539. [CrossRef]

15. Zavidij, O.; Haradhvala, N.J.; Mouhieddine, T.H.; Sklavenitis-Pistofidis, R.; Cai, S.; Reidy, M.; Rahmat, M.; Flaifel, A.; Ferland, B.; $\mathrm{Su}$, N.K.; et al. Single-cell RNA sequencing reveals compromised immune microenvironment in precursor stages of multiple myeloma. Nat. Cancer 2020, 1, 493-506. [CrossRef]

16. Dosani, T.; Carlsten, M.; Maric, I.; Landgren, O. The cellular immune system in myelomagenesis: NK cells and T cells in the development of myeloma and their uses in immunotherapies. Blood Cancer J. 2015, 5, e306. [CrossRef]

17. Maes, K.; Breckpot, K. Commentary: Immunogenic cell death and immunotherapy of multiple myeloma. Front. Cell Dev. Biol. 2019, 7, 149. [CrossRef]

18. Serrano-Del Valle, A.; Anel, A.; Naval, J.; Marzo, I. Immunogenic Cell Death and Immunotherapy of Multiple Myeloma. Front. Cell Dev. Biol. 2019, 7, 50. [CrossRef] [PubMed]

19. Bae, J.; Accardi, F.; Hideshima, T.; Tai, Y.T.; Prabhala, R.; Shambley, A.; Wen, K.; Rowell, S.; Richardson, P.G.; Munshi, N.C.; et al. Targeting LAG3/GAL-3 to overcome immunosuppression and enhance anti-tumor immune responses in multiple myeloma. Leukemia 2021, 36, 138-154. [CrossRef]

20. Ratta, M.; Fagnoni, F.; Curti, A.; Vescovini, R.; Sansoni, P.; Oliviero, B.; Fogli, M.; Ferri, E.; Della Cuna, G.R.; Tura, S.; et al Dendritic cells are functionally defective in multiple myeloma: The role of interleukin-6. Blood 2002, 100, 230-237. [CrossRef]

21. Brimnes, M.K.; Svane, I.M.; Johnsen, H.E. Impaired functionality and phenotypic profile of dendritic cells from patients with multiple myeloma. Clin. Exp. Immunol. 2006, 144, 76-84. [CrossRef]

22. De Veirman, K.; van Ginderachter, J.A.; Lub, S.; de Beule, N.; Thielemans, K.; Bautmans, I.; Oyajobi, B.O.; de Bruyne, E.; Menu, E.; Lemaire, M.; et al. Multiple myeloma induces Mcl-1 expression and survival of myeloid-derived suppressor cells. Oncotarget 2015, 6, 10532-10547. [CrossRef]

23. De Beule, N.; De Veirman, K.; Maes, K.; De Bruyne, E.; Menu, E.; Breckpot, K.; De Raeve, H.; Van Rampelbergh, R.; Van Ginderachter, J.A.; Schots, R.; et al. Tumour-associated macrophage-mediated survival of myeloma cells through STAT3 activation. J. Pathol. 2017, 241, 534-546. [CrossRef]

24. Beyer, M.; Kochanek, M.; Giese, T.; Endl, E.; Weihrauch, M.R.; Knolle, P.A.; Classen, S.; Schultze, J.L. In vivo peripheral expansion of naive CD4+CD25high FoxP3+ regulatory T cells in patients with multiple myeloma. Blood 2006, 107, 3940-3949. [CrossRef]

25. Weinstock, M.; Rosenblatt, J.; Avigan, D. Dendritic Cell Therapies for Hematologic Malignancies. Mol. Ther. Methods Clin. Dev. 2017, 5, 66-75. [CrossRef]

26. Banchereau, J.; Palucka, A.K. Dendritic cells as therapeutic vaccines against cancer. Nat. Rev. Immunol. 2005, 296-306. [CrossRef]

27. Wang, Y.; Xiang, Y.; Xin, V.W.; Wang, X.-W.; Peng, X.-C.; Liu, X.-Q.; Wang, D.; Li, N.; Cheng, J.-T.; Lyv, Y.-N.; et al. Dendritic cell biology and its role in tumor immunotherapy. J. Hematol. Oncol. 2020, 13, 107. [CrossRef] 
28. Carenza, C.; Calcaterra, F.; Oriolo, F.; Di Vito, C.; Ubezio, M.; Giovanni, M.; Porta, D.; Mavilio, D.; Della Bella, S.; Kane, L. Costimulatory Molecules and Immune Checkpoints Are Differentially Expressed on Different Subsets of Dendritic Cells. Front. Immunol. 2019, 10, 1325. [CrossRef]

29. Devito, N.C.; Plebanek, M.P.; Theivanthiran, B.; Hanks, B.A. Role of Tumor-Mediated Dendritic Cell Tolerization in Immune Evasion. Front. Immunol. 2019, 10, 2876. [CrossRef]

30. Binnewies, M.; Mujal, A.M.; Pollack, J.L.; Combes, A.J.; Hardison, E.A.; Barry, K.C.; Tsui, J.; Ruhland, M.K.; Kersten, K.; Abushawish, M.A.; et al. Unleashing Type-2 Dendritic Cells to Drive Protective Antitumor CD4(+) T Cell Immunity. Cell 2019, 177, 556-571.e16. [CrossRef]

31. Nguyen-Pham, T.N.; Lee, Y.K.; Kim, H.J.; Lee, J.J. Immunotherapy using dendritic cells against multiple myeloma: How to improve? Clin. Dev. Immunol. 2012, 2012, 397648. [CrossRef]

32. Yi, Q. Dendritic cell-based immunotherapy in multiple myeloma. Leuk. Lymphoma 2003, 44, 2031-2038. [CrossRef]

33. Steinman, R.M.; Cohn, Z.A. Identification of a novel cell type in peripheral lymphoid organs of mice: I. Morphology, quantitation, tissue distribution. J. Exp. Med. 1973, 137, 1142-1162. [CrossRef]

34. Guilliams, M.; Ginhoux, F.; Jakubzick, C.; Naik, S.H.; Onai, N.; Schraml, B.U.; Segura, E.; Tussiwand, R.; Yona, S. Dendritic cells, monocytes and macrophages: A unified nomenclature based on ontogeny. Nat. Rev. Immunol. 2014, 14, 571-578. [CrossRef]

35. Randolph, G.; Merad, M. Reply to: "Can DCs be distinguished from macrophages by molecular signatures? " Nat. Immunol. 2013, 14, 189-190. [CrossRef]

36. Hume, D.A.; Mabbott, N.; Raza, S.; Freeman, T.C. Can DCs be distinguished from macrophages by molecular signatures? Nat. Immunol. 2013, 14, 187-189. [CrossRef]

37. Helft, J.; Anjos-Afonso, F.; van der Veen, A.G.; Chakravarty, P.; Bonnet, D.; de Sousa, R.C. Dendritic Cell Lineage Potential in Human Early Hematopoietic Progenitors. Cell Rep. 2017, 20, 529-537. [CrossRef]

38. Schlitzer, A.; Sivakamasundari, V.; Chen, J.; Bin Sumatoh, H.R.; Schreuder, J.; Lum, J.; Malleret, B.; Zhang, S.; Larbi, A.; Zolezzi, F.; et al. Identification of $\mathrm{CDC} 1$ - and $\mathrm{cDC} 2$-committed DC progenitors reveals early lineage priming at the common DC progenitor stage in the bone marrow. Nat. Immunol. 2015, 16, 718-728. [CrossRef]

39. Dress, R.J.; Dutertre, C.-A.; Giladi, A.; Schlitzer, A.; Low, I.; Shadan, N.B.; Tay, A.; Lum, J.; Kairi, M.F.B.M.; Hwang, Y.Y.; et al. Plasmacytoid dendritic cells develop from $\operatorname{Ly} 6 \mathrm{D}(+)$ lymphoid progenitors distinct from the myeloid lineage. Nat. Immunol. 2019, 20, 852-864. [CrossRef]

40. Anderson, D.A.; Dutertre, C.A.; Ginhoux, F.; Murphy, K.M. Genetic models of human and mouse dendritic cell development and function. Nat. Rev. Immunol. 2021, 21, 101-115. [CrossRef]

41. Diao, J.; Winter, E.; Cantin, C.; Chen, W.; Xu, L.; Kelvin, D.; Phillips, J.; Cattral, M.S. In Situ Replication of Immediate Dendritic Cell (DC) Precursors Contributes to Conventional DC Homeostasis in Lymphoid Tissue. J. Immunol. 2006, 176, 7196-7206. [CrossRef] [PubMed]

42. Diao, J.; Winter, E.; Chen, W.; Cantin, C.; Cattral, M.S. Characterization of Distinct Conventional and Plasmacytoid Dendritic Cell-Committed Precursors in Murine Bone Marrow. J. Immunol. 2004, 173, 1826-1833. [CrossRef] [PubMed]

43. Liu, K.; Victora, G.D.; Schwickert, T.A.; Guermonprez, P.; Meredith, M.M.; Yao, K.; Chu, F.-F.; Randolph, G.J.; Rudensky, A.Y.; Nussenzweig, M. In Vivo Analysis of Dendritic Cell. Science 2009, 324, 392-397. [CrossRef]

44. Corcoran, L.; Ferrero, I.; Vremec, D.; Lucas, K.; Waithman, J.; O’Keeffe, M.; Wu, L.; Wilson, A.; Shortman, K. The Lymphoid Past of Mouse Plasmacytoid Cells and Thymic Dendritic Cells. J. Immunol. 2003, 170, 4926-4932. [CrossRef]

45. Pelayo, R.; Hirose, J.; Huang, J.; Garrett, K.P.; Delogu, A.; Busslinger, M.; Kincade, P.W. Derivation of 2 categories of plasmacytoid dendritic cells in murine bone marrow. Blood 2005, 105, 4407-4415. [CrossRef]

46. Musumeci, A.; Lutz, K.; Winheim, E.; Krug, A.B. What Makes a pDC: Recent Advances in Understanding Plasmacytoid DC Development and Heterogeneity. Front. Immunol. 2019, 10, 1222. [CrossRef]

47. Onai, N.; Obata-Onai, A.; Schmid, M.A.; Ohteki, T.; Jarrossay, D.; Manz, M.G. Identification of clonogenic common Flt3+M-CSFR+ plasmacytoid and conventional dendritic cell progenitors in mouse bone marrow. Nat. Immunol. 2007, 8, 1207-1216. [CrossRef]

48. Pulendran, B.; Banchereau, J.; Burkeholder, S.; Kraus, E.; Guinet, E.; Chalouni, C.; Caron, D.; Maliszewski, C.; Davoust, J.; Fay, J.; et al. Flt3-Ligand and Granulocyte Colony-Stimulating Factor Mobilize Distinct Human Dendritic Cell Subsets In Vivo. J. Immunol. 2000, 165, 566-572. [CrossRef]

49. Belz, G.T.; Nutt, S.L. Transcriptional programming of the dendritic cell network. Nat. Rev. Immunol. 2012, 12, 101-113. [CrossRef]

50. Bachem, A.; Güttler, S.; Hartung, E.; Ebstein, F.; Schaefer, M.; Tannert, A.; Salama, A.; Movassaghi, K.; Opitz, C.; Mages, H.W.; et al. Superior antigen cross-presentation and XCR1 expression define human CD11c+CD141+ cells as homologues of mouse CD8+ dendritic cells. J. Exp. Med. 2010, 207, 1273-1281. [CrossRef]

51. Contreras, V.; Urien, C.; Guiton, R.; Alexandre, Y.; Vu Manh, T.-P.; Andrieu, T.; Crozat, K.; Jouneau, L.; Bertho, N.; Epardaud, M.; et al. Existence of CD8 $\alpha$-Like Dendritic Cells with a Conserved Functional Specialization and a Common Molecular Signature in Distant Mammalian Species. J. Immunol. 2010, 185, 3313-3325. [CrossRef]

52. Dzionek, A.; Fuchs, A.; Schmidt, P.; Cremer, S.; Zysk, M.; Miltenyi, S.; Buck, D.W.; Schmitz, J. BDCA-2, BDCA-3, and BDCA-4: Three Markers for Distinct Subsets of Dendritic Cells in Human Peripheral Blood. J. Immunol. 2000, 165, 6037-6046. [CrossRef]

53. Guilliams, M.; Dutertre, C.A.; Scott, C.L.; McGovern, N.; Sichien, D.; Chakarov, S.; Van Gassen, S.; Chen, J.; Poidinger, M.; De Prijck, S.; et al. Unsupervised High-Dimensional Analysis Aligns Dendritic Cells across Tissues and Species. Immunity 2016, 45, 669-684. [CrossRef] [PubMed] 
54. Crozat, K.; Guiton, R.; Contreras, V.; Feuillet, V.; Dutertre, C.A.; Ventre, E.; Manh, T.P.V.; Baranek, T.; Storset, A.K.; Marvel, J.; et al. The XC chemokine receptor 1 is a conserved selective marker of mammalian cells homologous to mouse CD8 $\alpha+$ dendritic cells. J. Exp. Med. 2010, 207, 1283-1292. [CrossRef]

55. Qian, J.; Olbrecht, S.; Boeckx, B.; Vos, H.; Laoui, D.; Etlioglu, E.; Wauters, E.; Pomella, V.; Verbandt, S.; Busschaert, P.; et al. A pan-cancer blueprint of the heterogeneous tumor microenvironment revealed by single-cell profiling. Cell Res. 2020, 30, 745-762. [CrossRef] [PubMed]

56. Gerhard, G.M.; Bill, R.; Messemaker, M.; Klein, A.M.; Pittet, M.J. Tumor-infiltrating dendritic cell states are conserved across solid human cancers. J. Exp. Med. 2021, 218, e20200264. [CrossRef]

57. Maier, B.; Leader, A.M.; Chen, S.T.; Tung, N.; Chang, C.; LeBerichel, J.; Chudnovskiy, A.; Maskey, S.; Walker, L.; Finnigan, J.P.; et al. A conserved dendritic-cell regulatory program limits antitumour immunity. Nature 2020, 580, 257-262. [CrossRef]

58. Cheng, S.; Li, Z.; Gao, R.; Xing, B.; Gao, Y.; Yang, Y.; Qin, S.; Zhang, L.; Ouyang, H.; Du, P.; et al. A pan-cancer single-cell transcriptional atlas of tumor infiltrating myeloid cells. Cell 2021, 184, 792-809.e23. [CrossRef]

59. Hacker, C.; Kirsch, R.D.; Ju, X.S.; Hieronymus, T.; Gust, T.C.; Kuhl, C.; Jorgas, T.; Kurz, S.M.; Rose-John, S.; Yokota, Y.; et al. Transcriptional profiling identifies Id2 function in dendritic cell development. Nat. Immunol. 2003, 4, 380-386. [CrossRef]

60. Hildner, K.; Edelson, B.T.; Purtha, W.E.; Diamond, M.; Matsushita, H.; Kohyama, M.; Calderon, B.; Schraml, B.U.; Unanue, E.R.; Diamond, M.S.; et al. Batf3 deficiency reveals a critical role for CD8 $\alpha+$ dendritic cells in cytotoxic T cell immunity. Science 2008, 322, 1097-1100. [CrossRef]

61. Kashiwada, M.; Pham, N.L.L.; Pewe, L.L.; Harty, J.T.; Rothman, P.B. NFIL3/E4BP4 is a key transcription factor for CD8 $\alpha+$ dendritic cell development. Blood 2011, 117, 6193-6197. [CrossRef]

62. Tamura, T.; Tailor, P.; Yamaoka, K.; Kong, H.J.; Tsujimura, H.; O'Shea, J.J.; Singh, H.; Ozato, K. IFN Regulatory Factor-4 and -8 Govern Dendritic Cell Subset Development and Their Functional Diversity. J. Immunol. 2005, 174, 2573-2581. [CrossRef]

63. Seillet, C.; Jackson, J.T.; Markey, K.A.; Brady, H.J.M.; Hill, G.R.; MacDonald, K.P.A.; Nutt, S.L.; Belz, G.T. CD8 $\alpha+$ DCs can be induced in the absence of transcription factors Id2, Nfil3, and Batf3. Blood 2013, 121, 1574-1583. [CrossRef] [PubMed]

64. Scott, C.L.; Soen, B.; Martens, L.; Skrypek, N.; Saelens, W.; Taminau, J.; Blancke, G.; Van Isterdael, G.; Huylebroeck, D.; Haigh, J.; et al. The transcription factor Zeb2 regulates development of conventional and plasmacytoid DCs by repressing Id2. J. Exp. Med. 2016, 213, 897-911. [CrossRef]

65. Wu, L.; D’Amico, A.; Winkel, K.D.; Suter, M.; Lo, D.; Shortman, K. RelB is essential for the development of myeloid-related CD8 $\alpha-$ dendritic cells but not of lymphoid-related CD8 $\alpha+$ dendritic cells. Immunity 1998, 9, 839-847. [CrossRef]

66. Guerriero, A.; Langmuir, P.B.; Spain, L.M.; Scott, E.W.P. 1 is required for myeloid-derived but not lymphoid-derived dendritic cells. Blood 2000, 95, 879-885. [CrossRef]

67. Caton, M.L.; Smith-Raska, M.R.; Reizis, B. Notch-RBP-J signaling controls the homeostasis of CD8- dendritic cells in the spleen. J. Exp. Med. 2007, 204, 1653-1664. [CrossRef] [PubMed]

68. Lewis, K.L.; Caton, M.L.; Bogunovic, M.; Greter, M.; Grajkowska, L.T.; Ng, D.; Klinakis, A.; Charo, I.F.; Jung, S.; Gommerman, J.L.; et al. Notch2 receptor signaling controls functional differentiation of dendritic cells in the spleen and intestine. Immunity 2011, 35, 780-791. [CrossRef]

69. Ichikawa, E.; Hida, S.; Omatsu, Y.; Shimoyama, S.; Takahara, K.; Miyagawa, S.; Inaba, K.; Taki, S. Defective development of splenic and epidermal CD4+ dendritic cells in mice deficient for IFN regulatory factor-2. Proc. Natl. Acad. Sci. USA 2004, 101, 3909-3914. [CrossRef] [PubMed]

70. Brown, C.C.; Gudjonson, H.; Pritykin, Y.; Deep, D.; Lavallée, V.P.; Mendoza, A.; Fromme, R.; Mazutis, L.; Ariyan, C.; Leslie, C.; et al. Transcriptional Basis of Mouse and Human Dendritic Cell Heterogeneity. Cell 2019, 179, 846-863.e24. [CrossRef] [PubMed]

71. Villani, A.C.; Satija, R.; Reynolds, G.; Sarkizova, S.; Shekhar, K.; Fletcher, J.; Griesbeck, M.; Butler, A.; Zheng, S.; Lazo, S.; et al. Single-cell RNA-seq reveals new types of human blood dendritic cells, monocytes, and progenitors. Science 2017, 356, eaah4573. [CrossRef]

72. Dutertre, C.A.; Becht, E.; Irac, S.E.; Khalilnezhad, A.; Narang, V.; Khalilnezhad, S.; Ng, P.Y.; van den Hoogen, L.L.; Leong, J.Y.; Lee, B.; et al. Single-Cell Analysis of Human Mononuclear Phagocytes Reveals Subset-Defining Markers and Identifies Circulating Inflammatory Dendritic Cells. Immunity 2019, 51, 573-589.e8. [CrossRef]

73. Kingston, D.; Schmid, M.A.; Onai, N.; Obata-Onai, A.; Baumjohann, D.; Manz, M.G. The concerted action of GM-CSF and Flt3-ligand on in vivo dendritic cell homeostasis. Blood 2009, 114, 835-843. [CrossRef] [PubMed]

74. Cisse, B.; Caton, M.L.; Lehner, M.; Maeda, T.; Scheu, S.; Locksley, R.; Holmberg, D.; Zweier, C.; Hollander, N.S.; Kant, G.; et al. Transcription factor E2-2 is an essential and specific regulator of plasmacytoid dendritic cell development. Cell 2008, 135, 37-48. [CrossRef] [PubMed]

75. Schotte, R.; Nagasawa, M.; Weijer, K.; Spits, H.; Blom, B. The ETS transcription factor Spi-B is required for human plasmacytoid dendritic cell development. J. Exp. Med. 2004, 200, 1503-1509. [CrossRef]

76. Hochrein, H.; O’Keeffe, M.; Wagner, H. Human and mouse plasmacytoid dendritic cells. Hum. Immunol. 2002, 63, 1103-1110. [CrossRef]

77. Serbina, N.V.; Salazar-Mather, T.P.; Biron, C.A.; Kuziel, W.A.; Pamer, E.G. TNF/iNOS-producing dendritic cells mediate innate immune defense against bacterial infection. Immunity 2003, 19, 59-70. [CrossRef] 
78. Lehtonen, A.; Veckman, V.; Nikula, T.; Lahesmaa, R.; Kinnunen, L.; Matikainen, S.; Julkunen, I. Differential Expression of IFN Regulatory Factor 4 Gene in Human Monocyte-Derived Dendritic Cells and Macrophages. J. Immunol. 2005, 175, 6570-6579. [CrossRef] [PubMed]

79. Plantinga, M.; Guilliams, M.; Vanheerswynghels, M.; Deswarte, K.; Branco-Madeira, F.; Toussaint, W.; Vanhoutte, L.; Neyt, K.; Killeen, N.; Malissen, B.; et al. Conventional and Monocyte-Derived CD11b+ Dendritic Cells Initiate and Maintain T Helper 2 Cell-Mediated Immunity to House Dust Mite Allergen. Immunity 2013, 38, 322-335. [CrossRef]

80. Segura, E.; Touzot, M.; Bohineust, A.; Cappuccio, A.; Chiocchia, G.; Hosmalin, A.; Dalod, M.; Soumelis, V.; Amigorena, S. Human Inflammatory Dendritic Cells Induce Th17 Cell Differentiation. Immunity 2013, 38, 336-348. [CrossRef]

81. Garg, A.D.; Nowis, D.; Golab, J.; Vandenabeele, P.; Krysko, D.V.; Agostinis, P. Immunogenic cell death, DAMPs and anticancer therapeutics: An emerging amalgamation. Biochim. Biophys. Acta 2010, 1805, 53-71. [CrossRef]

82. Dudek, A.M.; Martin, S.; Garg, A.D.; Agostinis, P. Immature, semi-mature, and fully mature dendritic cells: Toward a DC-cancer cells interface that augments anticancer immunity. Front. Immunol. 2013, 4, 438. [CrossRef] [PubMed]

83. Théry, C.; Amigorena, S. The cell biology of antigen presentation in dendritic cells. Curr. Opin. Immunol. 2001, 13, 45-51. [CrossRef]

84. Tiberio, L.; Del Prete, A.; Schioppa, T.; Sozio, F.; Bosisio, D.; Sozzani, S. Chemokine and chemotactic signals in dendritic cell migration review-article. Cell. Mol. Immunol. 2018, 15, 346-352. [CrossRef] [PubMed]

85. Gunn, M.D. Chemokine mediated control of dendritic cell migration and function. Semin. Immunol. 2003, 15, 271-276. [CrossRef] [PubMed]

86. Randolph, G.J.; Angeli, V.; Swartz, M.A. Dendritic-cell trafficking to lymph nodes through lymphatic vessels. Nat. Rev. Immunol. 2005, 5, 617-628. [CrossRef]

87. Hilligan, K.L.; Ronchese, F. Antigen presentation by dendritic cells and their instruction of CD4+ T helper cell responses. Cell. Mol. Immunol. 2020, 17, 587-599. [CrossRef]

88. Guermonprez, P.; Valladeau, J.; Zitvogel, L.; Théry, C.; Amigorena, S. Antigen presentation and T cell stimulation by dendritic cells. Annu. Rev. Immunol. 2002, 20, 621-667. [CrossRef] [PubMed]

89. Colbert, J.D.; Cruz, F.M.; Rock, K.L. Cross-presentation of exogenous antigens on MHC I molecules. Curr. Opin. Immunol. 2020, 64, 1-8. [CrossRef]

90. Den Haan, J.M.M.; Lehar, S.M.; Bevan, M.J. CD8+ but not CD8- dendritic cells cross-prime cytotoxic T cells in vivo. J. Exp. Med. 2000, 192, 1685-1695. [CrossRef]

91. Tussiwand, R.; Everts, B.; Grajales-Reyes, G.E.; Kretzer, N.M.; Iwata, A.; Bagaitkar, J.; Wu, X.; Wong, R.; Anderson, D.A.; Murphy, T.L.; et al. Klf4 Expression in Conventional Dendritic Cells Is Required for T Helper 2 Cell Responses. Immunity 2015, 42, 916-928. [CrossRef] [PubMed]

92. Duong, E.; Fessenden, T.B.; Lutz, E.; Dinter, T.; Yim, L.; Blatt, S.; Bhutkar, A.; Wittrup, K.D.; Spranger, S. Type I interferon activates MHC class I-dressed CD11b+ conventional dendritic cells to promote protective anti-tumor CD8+ T cell immunity. Immunity 2021, online ahead of print. [CrossRef]

93. Bosteels, C.; Neyt, K.; Vanheerswynghels, M.; van Helden, M.J.; Sichien, D.; Debeuf, N.; De Prijck, S.; Bosteels, V.; Vandamme, N.; Martens, L.; et al. Inflammatory Type 2 cDCs Acquire Features of cDC1s and Macrophages to Orchestrate Immunity to Respiratory Virus Infection. Immunity 2020, 52, 1039-1056.e9. [CrossRef]

94. Murgaski, A.; Bardet, P.M.R.; Arnouk, S.M.; Clappaert, E.J.; Laoui, D. Unleashing tumour-dendritic cells to fight cancer by tackling their three A's: Abundance, activation and antigen-delivery. Cancers 2019, 11, 670. [CrossRef]

95. Reizis, B.; Bunin, A.; Ghosh, H.S.; Lewis, K.L.; Sisirak, V. Plasmacytoid dendritic cells: Recent progress and open questions. Annu. Rev. Immunol. 2011, 29, 163-183. [CrossRef] [PubMed]

96. Conrad, C.; Gregorio, J.; Wang, Y.H.; Ito, T.; Meller, S.; Hanabuchi, S.; Anderson, S.; Atkinson, N.; Ramirez, P.T.; Liu, Y.J.; et al. Plasmacytoid dendritic cells promote immunosuppression in ovarian cancer via ICOS costimulation of Foxp3+ T-regulatory cells. Cancer Res. 2012, 72, 5240-5249. [CrossRef] [PubMed]

97. Robbins, S.H.; Walzer, T.; Dembélé, D.; Thibault, C.; Defays, A.; Bessou, G.; Xu, H.; Vivier, E.; Sellars, M.; Pierre, P.; et al. Novel insights into the relationships between dendritic cell subsets in human and mouse revealed by genome-wide expression profiling. Genome Biol. 2008, 9, 1-27. [CrossRef]

98. Laoui, D.; Keirsse, J.; Morias, Y.; Van Overmeire, E.; Geeraerts, X.; Elkrim, Y.; Kiss, M.; Bolli, E.; Lahmar, Q.; Sichien, D.; et al. The tumour microenvironment harbours ontogenically distinct dendritic cell populations with opposing effects on tumour immunity. Nat. Commun. 2016, 7, 13720. [CrossRef]

99. Bakdash, G.; Buschow, S.I.; Gorris, M.A.J.; Halilovic, A.; Hato, S.V.; Sköld, A.E.; Schreibelt, G.; Sittig, S.P.; Torensma, R.; Duiveman-De Boer, T.; et al. Expansion of a BDCA1+ CD14+ myeloid cell population in melanoma patients may attenuate the efficacy of dendritic cell vaccines. Cancer Res. 2016, 76, 4332-4346. [CrossRef]

100. Shinde, P.; Fernandes, S.; Melinkeri, S.; Kale, V.; Limaye, L. Compromised functionality of monocyte-derived dendritic cells in multiple myeloma patients may limit their use in cancer immunotherapy. Sci. Rep. 2018, 8, 5705. [CrossRef]

101. Do, T.H.; Johnsen, H.E.; Kjærsgaard, E.; Taaning, E.; Svane, I.M. Impaired circulating myeloid DCs from myeloma patients. Cytotherapy 2004, 6, 196-203. [CrossRef] [PubMed]

102. Fearnley, D.B.; Whyte, L.F.; Carnoutsos, S.A.; Cook, A.H.; Hart, D.N.J. Monitoring human blood dendritic cell numbers in normal individuals and in stem cell transplantation. Blood 1999, 93, 728-736. [CrossRef] [PubMed] 
103. Upham, J.W.; Lundahl, J.; Liang, H.; Denburg, J.A.; O’Byrne, P.M.; Snider, D.P. Simplified quantitation of myeloid dendritic cells in peripheral blood using flow cytometry. Cytometry 2000, 40, 50-59. [CrossRef]

104. Leone, P.; Berardi, S.; Frassanito, M.A.; Ria, R.; De Re, V.; Cicco, S.; Battaglia, S.; Ditonno, P.; Dammacco, F.; Vacca, A.; et al. Dendritic cells accumulate in the bone marrow of myeloma patients where they protect tumor plasma cells from CD8+ T-cell killing. Blood 2015, 126, 1443-1451. [CrossRef] [PubMed]

105. Ray, A.; Das, D.S.; Song, Y.; Macri, V.; Richardson, P.; Brooks, C.L.; Chauhan, D.; Anderson, K.C. A novel agent SL-401 induces anti-myeloma activity by targeting plasmacytoid dendritic cells, osteoclastogenesis and cancer stem-like cells. Leukemia 2017, 31, 2652-2660. [CrossRef]

106. Melillo, J.A.; Song, L.; Bhagat, G.; Blazquez, A.B.; Plumlee, C.R.; Lee, C.; Berin, C.; Reizis, B.; Schindler, C. Dendritic cell (DC)-specific targeting reveals Stat3 as a negative regulator of DC function. J. Immunol. 2010, 184, 2638-2645. [CrossRef]

107. Yao, Y.; Xu, Q.; Kwon, M.-J.; Matta, R.; Liu, Y.; Hong, S.-C.; Chang, C.-H. ERK and p38 MAPK signaling pathways negatively regulate CIITA gene expression in dendritic cells and macrophages. J. Immunol. 2006, 177, 70-76. [CrossRef]

108. Brown, R.; Murray, A.; Pope, B.; Sze, D.M.; Gibson, J.; Ho, P.J.; Hart, D.; Joshua, D. Either interleukin-12 or interferon- $\gamma$ can correct the dendritic cell defect induced by transforming growth factor $\beta 1$ in patients with myeloma. Br. J. Haematol. 2004, 125, 743-748. [CrossRef]

109. Brown, R.D.; Pope, B.; Murray, A.; Esdale, W.; Sze, D.M.; Gibson, J.; Joy Ho, P.; Hart, D.; Joshua, D. Dendritic cells from patients with myeloma are numerically normal but functionally defective as they fail to up-regulate CD80 (B7-1) expression after huCD40LT stimulation because of inhibition by transforming growth factor- $\beta 1$ and interleukin-10. Blood 2001, 98, $2992-2998$. [CrossRef]

110. Zelante, T.; Fric, J.; Wong, A.Y.W.; Ricciardi-Castagnoli, P. Interleukin-2 production by dendritic cells and its immuno-regulatory functions. Front. Immunol. 2012, 3, 161. [CrossRef]

111. Gabrilovich, D.; Ishida, T.; Oyama, T.; Ran, S.; Kravtsov, V.; Nadaf, S.; Carbone, D.P. Vascular endothelial growth factor inhibits the development of dendritic cells and dramatically affects the differentiation of multiple hematopoietic lineages in vivo. Blood 1998, 92, 4150-4166. [CrossRef]

112. Takahashi, A.; Kono, K.; Ichihara, F.; Sugai, H.; Fujii, H.; Matsumoto, Y. Vascular endothelial growth factor inhibits maturation of dendritic cells induced by lipopolysaccharide, but not by proinflammatory cytokines. Cancer Immunol. Immunother. 2004, 53, 543-550. [CrossRef] [PubMed]

113. Wang, S.; Yang, J.; Qian, J.; Wezeman, M.; Kwak, L.W.; Yi, Q. Tumor evasion of the immune system: Inhibiting p38 MAPK signaling restores the function of dendritic cells in multiple myeloma. Blood 2006, 107, 2432-2439. [CrossRef] [PubMed]

114. Rutella, S.; Locatelli, F. Targeting multiple-myeloma-induced immune dysfunction to improve immunotherapy outcomes. Clin. Dev. Immunol. 2012, 2012, 196063. [CrossRef] [PubMed]

115. Österborg, A.; Yi, Q.; Henriksson, L.; Fagerberg, J.; Bergenbrant, S.; Jeddi-Tehrani, M.; Rudén, U.; Lefvert, A.-K.; Holm, G.; Mellstedt, H. Idiotype Immunization Combined with Granulocyte-Macrophage Colony-Stimulating Factor in Myeloma Patients Induced Type I, Major Histocompatibility Complex-Restricted, CD8- and CD4-Specific T-Cell Responses. Blood 1998, 91, $2459-2466$. [CrossRef]

116. Coscia, M.; Mariani, S.; Battaglio, S.; Di Bello, C.; Fiore, F.; Foglietta, M.; Pileri, A.; Boccadoro, M.; Massaia, M. Long-term follow-up of idiotype vaccination in human myeloma as a maintenance therapy after high-dose chemotherapy. Leukemia 2004, 18, 139-145. [CrossRef]

117. Dabadghao, S.; Bergenbrant, S.; Anton, D.; He, W.; Holm, G.; Yi, Q. Anti-idiotypic T-cell activation in multiple myeloma induced by M- component fragments presented by dendritic cells. Br. J. Haematol. 1998, 100, 647-654. [CrossRef]

118. Hopewell, E.L.; Cox, C. Manufacturing Dendritic Cells for Immunotherapy: Monocyte Enrichment. Mol. Ther. Methods Clin. Dev. 2020, 16, 155-160. [CrossRef]

119. Sabado, R.L.; Balan, S.; Bhardwaj, N. Dendritic cell-based immunotherapy. Cell Res. 2017, 27, 74-95. [CrossRef]

120. Wen, Y.J.; Ling, M.; Bailey-Wood, R.; Lim, S.H. Idiotypic protein-pulsed adherent peripheral blood mononuclear cell-derived dendritic cells prime immune system in multiple myeloma. Clin. Cancer Res. 1998, 4, 957-962.

121. Reichardt, V.L.; Okada, C.Y.; Liso, A.; Benike, C.J.; Stockerl-Goldstein, K.E.; Engleman, E.G.; Blume, K.G.; Levy, R. Idiotype vaccination using dendritic cells after autologous peripheral blood stem cell transplantation for multiple myeloma-A feasibility study. Blood 1999, 93, 2411-2419. [CrossRef] [PubMed]

122. Lacy, M.Q.; Mandrekar, S.; Dispenzieri, A.; Hayman, S.; Kumar, S.; Buadi, F.; Dingli, D.; Litzow, M.; Wettstein, P.; Padley, D.; et al. Idiotype-pulsed antigen-presenting cells following autologous transplantation for multiple myeloma may be associated with prolonged survival. Am. J. Hematol. 2009, 84, 799-802. [CrossRef]

123. Röllig, C.; Schmidt, C.; Bornhäuser, M.; Ehninger, G.; Schmitz, M.; Auffermann-Gretzinger, S. Induction of cellular immune responses in patients with stage-I multiple myeloma after vaccination with autologous idiotype-pulsed dendritic cells. J. Immunother. 2011, 34, 100-106. [CrossRef] [PubMed]

124. Yi, Q.; Szmania, S.; Freeman, J.; Qian, J.; Rosen, N.A.; Viswamitra, S.; Cottler-Fox, M.; Barlogie, B.; Tricot, G.; van Rhee, F. Optimizing dendritic cell-based immunotherapy in multiple myeloma: Intranodal injections of idiotype-pulsed CD40 ligandmatured vaccines led to induction of type-1 and cytotoxic T-cell immune responses in patients. Br. J. Haematol. 2010, 150, 554-564. [CrossRef] 
125. Zahradova, L.; Mollova, K.; Ocadlikova, D.; Kovarova, L.; Adam, Z.; Krejci, M.; Pour, L.; Krivanova, A.; Sandecka, V.; Hajek, R. Efficacy and safety of Id-protein-loaded dendritic cell vaccine in patients with multiple myeloma-phase II study results. Neoplasma 2012, 59, 440-449. [CrossRef] [PubMed]

126. Cull, G.; Durrant, L.; Stainer, C.; Haynes, A.; Russell, N. Generation of anti-idiotype immune responses following vaccination with idiotype-protein pulsed dendritic cells in myeloma. Br. J. Haematol. 1999, 107, 648-655. [CrossRef]

127. Lim, S.H.; Bailey-Wood, R. Idiotypic protein-pulsed dendritic cell vaccination in multiple myeloma. Int. J. Cancer 1999, 83, 215-222. [CrossRef]

128. Titzer, S.; Christensen, O.; Manzke, O.; Tesch, H.; Wolf, J.; Emmerich, B.; Carsten, C.; Diehl, V.; Bohlen, H. Vaccination of multiple myeloma patients with idiotype-pulsed dendritic cells: Immunological and clinical aspects. Br. J. Haematol. 2000, 108, 805-816. [CrossRef]

129. Liso, A.; Stockerl-Goldstein, K.E.; Auffermann-Gretzinger, S.; Benike, C.J.; Reichardt, V.; van Beckhoven, A.; Rajapaksa, R.; Engleman, E.G.; Blume, K.G.; Levy, R. Idiotype vaccination using dendritic cells after autologous peripheral blood progenitor cell transplantation for multiple myeloma. J. Am. Soc. Blood Marrow Transplant. 2000, 6, 621-627. [CrossRef]

130. Yi, Q.; Desikan, R.; Barlogie, B.; Munshi, N. Optimizing dendritic cell-based immunotherapy in multiple myeloma. Br. J. Haematol. 2002, 117, 297-305. [CrossRef]

131. Reichardt, V.L.; Milazzo, C.; Brugger, W.; Einsele, H.; Kanz, L.; Brossart, P. Idiotype vaccination of multiple myeloma patients using monocyte-derived dendritic cells. Haematologica 2003, 88, 1139-1149.

132. Bendandi, M.; Rodríguez-Calvillo, M.; Inogés, S.; López-Díaz de Cerio, A.; Pérez-Simón, J.A.; Rodríguez-Caballero, A.; García-Montero, A.; Almeida, J.; Zabalegui, N.; Giraldo, P.; et al. Combined vaccination with idiotype-pulsed allogeneic dendritic cells and soluble protein idiotype for multiple myeloma patients relapsing after reduced-intensity conditioning allogeneic stem cell transplantation. Leuk. Lymphoma 2006, 47, 29-37. [CrossRef]

133. Curti, A.; Tosi, P.; Comoli, P.; Terragna, C.; Ferri, E.; Cellini, C.; Massaia, M.; D'Addio, A.; Giudice, V.; Di Bello, C.; et al. Phase I/II clinical trial of sequential subcutaneous and intravenous delivery of dendritic cell vaccination for refractory multiple myeloma using patient-specific tumour idiotype protein or idiotype (VDJ)-derived class I-restricted peptides. Br. J. Haematol. 2007, 139, 415-424. [CrossRef] [PubMed]

134. Hobo, W.; Strobbe, L.; Maas, F.; Fredrix, H.; Greupink-Draaisma, A.; Esendam, B.; De Witte, T.; Preijers, F.; Levenga, H.; Van Rees, B.; et al. Immunogenicity of dendritic cells pulsed with MAGE3, Survivin and B-cell maturation antigen mRNA for vaccination of multiple myeloma patients. Cancer Immunol. Immunother. 2013, 62, 1381-1392. [CrossRef] [PubMed]

135. Rosenblatt, J.; Vasir, B.; Uhl, L.; Blotta, S.; Macnamara, C.; Somaiya, P.; Wu, Z.; Joyce, R.; Levine, J.D.; Dombagoda, D.; et al. Vaccination with dendritic cell/tumor fusion cells results in cellular and humoral antitumor immune responses in patients with multiple myeloma. Blood 2011, 117, 393-402. [CrossRef] [PubMed]

136. Rosenblatt, J.; Avivi, I.; Vasir, B.; Uhl, L.; Munshi, N.C.; Katz, T.; Dey, B.R.; Somaiya, P.; Mills, H.; Campigotto, F.; et al. Vaccination with dendritic cell/tumor fusions following autologous stem cell transplant induces immunologic and clinical responses in multiple myeloma patients. Clin. Cancer Res. 2013, 19, 3640-3648. [CrossRef]

137. Jung, S.-H.; Lee, H.-J.; Lee, Y.-K.; Yang, D.-H.; Kim, H.-J.; Rhee, J.H.; Emmrich, F.; Lee, J.-J. A phase I clinical study of autologous dendritic cell therapy in patients with relapsed or refractory multiple myeloma. Oncotarget 2017, 8, 41538-41548. [CrossRef]

138. Ocadlikova, D.; Kryukov, F.; Mollova, K.; Kovarova, L.; Buresdova, I.; Matejkova, E.; Penka, M.; Buchler, T.; Hajek, R.; Michalek, J. Generation of myeloma-specific T cells using dendritic cells loaded with MUC1- and hTERT- drived nonapeptides or myeloma cell apoptotic bodies. Neoplasma 2010, 57, 455-464. [CrossRef]

139. Li, R.; Qian, J.; Zhang, W.; Fu, W.; Du, J.; Jiang, H.; Zhang, H.; Zhang, C.; Xi, H.; Yi, Q.; et al. Human heat shock protein-specific cytotoxic T lymphocytes display potent antitumour immunity in multiple myeloma. Br. J. Haematol. 2014, 166, 690-701. [CrossRef] [PubMed]

140. Lim, S.H.; Wang, Z.; Chiriva-Internati, M.; Xue, Y. Sperm protein 17 is a novel cancer-testis antigen in multiple myeloma. Blood 2001, 97, 1508-1510. [CrossRef]

141. Qian, J.; Xie, J.; Hong, S.; Yang, J.; Zhang, L.; Han, X.; Wang, M.; Zhan, F.; Shaughnessy, J.D.J.; Epstein, J.; et al. Dickkopf-1 (DKK1) is a widely expressed and potent tumor-associated antigen in multiple myeloma. Blood 2007, 110, 1587-1594. [CrossRef]

142. Anderson, L.D.J.; Cook, D.R.; Yamamoto, T.N.; Berger, C.; Maloney, D.G.; Riddell, S.R. Identification of MAGE-C1 (CT-7) epitopes for T-cell therapy of multiple myeloma. Cancer Immunol. Immunother. 2011, 60, 985-997. [CrossRef]

143. Batchu, R.B.; Moreno, A.M.; Szmania, S.M.; Bennett, G.; Spagnoli, G.C.; Ponnazhagan, S.; Barlogie, B.; Tricot, G.; van Rhee, F. Protein transduction of dendritic cells for NY-ESO-1-based immunotherapy of myeloma. Cancer Res. 2005, 65, 10041-10049. [CrossRef]

144. Shires, K.; Van Wyk, T. The role of Cancer/Testis Antigens in Multiple Myeloma pathogenesis and their application in disease monitoring and therapy. Crit. Rev. Oncol. Hematol. 2018, 132, 17-26. [CrossRef] [PubMed]

145. Garg, A.D.; Coulie, P.G.; Van den Eynde, B.J.; Agostinis, P. Integrating Next-Generation Dendritic Cell Vaccines into the Current Cancer Immunotherapy Landscape. Trends Immunol. 2017, 38, 577-593. [CrossRef]

146. Gilboa, E.; Nair, S.K.; Lyerly, H.K. Immunotherapy of cancer with dendritic-cell-based vaccines. Cancer Immunol. Immunother. 1998, 46, 82-87. [CrossRef] [PubMed] 
147. Vasileiou, S.; Baltadakis, I.; Delimpasi, S.; Karatza, M.-H.; Liapis, K.; Garofalaki, M.; Tziotziou, E.; Poulopoulou, Z.; Karakasis, D.; Harhalakis, N. Ex Vivo Induction of Multiple Myeloma-specific Immune Responses by Monocyte-derived Dendritic Cells Following Stimulation by Whole-tumor Antigen of Autologous Myeloma Cells. J. Immunother. 2017, 40, 253-264. [CrossRef]

148. Hájek, R.; Butch, A.W. Dendritic cell biology and the application of dendritic cells to immunotherapy of multiple myeloma. Med. Oncol. 2000, 17, 2-15. [CrossRef] [PubMed]

149. van Gulijk, M.; Dammeijer, F.; Aerts, J.G.J.V.; Vroman, H. Combination Strategies to Optimize Efficacy of Dendritic Cell-Based Immunotherapy. Front. Immunol. 2018, 9, 2759. [CrossRef]

150. Dong, H.; Strome, S.E.; Salomao, D.R.; Tamura, H.; Hirano, F.; Flies, D.B.; Roche, P.C.; Lu, J.; Zhu, G.; Tamada, K.; et al. Tumor-associated B7-H1 promotes T-cell apoptosis: A potential mechanism of immune evasion. Nat. Med. 2002, 8, 793-800. [CrossRef]

151. Rosenblatt, J.; Glotzbecker, B.; Mills, H.; Vasir, B.; Tzachanis, D.; Levine, J.D.; Joyce, R.M.; Wellenstein, K.; Keefe, W.; Schickler, M.; et al. PD-1 blockade by CT-011, anti-PD-1 antibody, enhances ex vivo T-cell responses to autologous dendritic cell/myeloma fusion vaccine. J. Immunother. 2011, 34, 409-418. [CrossRef]

152. Luptakova, K.; Rosenblatt, J.; Glotzbecker, B.; Mills, H.; Stroopinsky, D.; Kufe, T.; Vasir, B.; Arnason, J.; Tzachanis, D.; Zwicker, J.I.; et al. Lenalidomide enhances anti-myeloma cellular immunity. Cancer Immunol. Immunother. 2013, 62, 39-49. [CrossRef] [PubMed]

153. Nguyen-Pham, T.-N.; Jung, S.-H.; Vo, M.; Lee, H.J.; Hoang, M.-D.; Choi, N.; Kim, H.-J.; Lee, J.-J. Lenalidomide Synergistically Enhances the Effect of Dendritic Cell Vaccination in Mouse Multiple Myeloma Model. Blood 2012, 120, 5010. [CrossRef]

154. Vo, M.-C.; Yang, S.; Jung, S.-H.; Chu, T.-H.; Lee, H.-J.; Lakshmi, T.J.; Park, H.-S.; Kim, H.-J.; Lee, J.-J. Synergistic Antimyeloma Activity of Dendritic Cells and Pomalidomide in a Murine Myeloma Model. Front. Immunol. 2018, 9, 1798. [CrossRef] [PubMed]

155. Chu, T.-H.; Vo, M.-C.; Park, H.-S.; Lakshmi, T.J.; Jung, S.-H.; Kim, H.-J.; Lee, J.-J. Potent anti-myeloma efficacy of dendritic cell therapy in combination with pomalidomide and programmed death-ligand 1 blockade in a preclinical model of multiple myeloma. Cancer Immunol. Immunother. 2021, 70, 31-45. [CrossRef]

156. Zeng, J.; Wu, C.; Wang, S. Antigenically Modified Human Pluripotent Stem Cells Generate Antigen-Presenting Dendritic Cells. Sci. Rep. 2015, 5, 15262. [CrossRef] [PubMed]

157. Shinde, P.; Melinkeri, S.; Santra, M.K.; Kale, V.; Limaye, L. Autologous Hematopoietic Stem Cells Are a Preferred Source to Generate Dendritic Cells for Immunotherapy in Multiple Myeloma Patients. Front. Immunol. 2019, 10, 1079. [CrossRef]

158. Prue, R.L.; Vari, F.; Radford, K.J.; Tong, H.; Hardy, M.Y.; D’Rozario, R.; Waterhouse, N.J.; Rossetti, T.; Coleman, R.; Tracey, C.; et al. A phase I clinical trial of CD1c (BDCA-1)+ dendritic cells pulsed with HLA-A*0201 peptides for immunotherapy of metastatic hormone refractory prostate cancer. J. Immunother. 2015, 38, 71-76. [CrossRef]

159. Schreibelt, G.; Bol, K.F.; Westdorp, H.; Wimmers, F.; Aarntzen, E.H.J.G.; Duiveman-de Boer, T.; van de Rakt, M.W.M.M.; Scharenborg, N.M.; de Boer, A.J.; Pots, J.M.; et al. Effective Clinical Responses in Metastatic Melanoma Patients after Vaccination with Primary Myeloid Dendritic Cells. Clin. Cancer Res. 2016, 22, 2155-2166. [CrossRef]

160. Rapoport, A.P.; Stadtmauer, E.A.; Aqui, N.; Badros, A.; Cotte, J.; Chrisley, L.; Veloso, E.; Zheng, Z.; Westphal, S.; Mair, R.; et al. Restoration of immunity in lymphopenic individuals with cancer by vaccination and adoptive T-cell transfer. Nat. Med. 2005, 11, 1230-1237. [CrossRef] 